\title{
Article
}

\section{The Impact of Income Inequality on Subjective Environmental Pollution: Individual Evidence from China}

\author{
Baoxi Li ${ }^{1,2}$ and De Xiao ${ }^{1,2, *}$ \\ 1 Research Center of Open Economy, Hubei University, Wuhan 430062, China; baoxili@stu.hubu.edu.cn \\ 2 School of Business, Hubei University, Wuhan 430062, China \\ * Correspondence: xiaode@hubu.edu.cn; Tel.: +86-13707102405
}

Citation: Li, B.; Xiao, D. The Impact of Income Inequality on Subjective Environmental Pollution: Individual Evidence from China. Int. J. Environ. Res. Public Health 2021, 18, 8090. https: / / doi.org/10.3390/ ijerph18158090

Academic Editors: Guy Hutton and Paul B. Tchounwou

Received: 8 June 2021

Accepted: 27 July 2021

Published: 30 July 2021

Publisher's Note: MDPI stays neutral with regard to jurisdictional claims in published maps and institutional affiliations.

Copyright: (c) 2021 by the authors. Licensee MDPI, Basel, Switzerland. This article is an open access article distributed under the terms and conditions of the Creative Commons Attribution (CC BY) license (https:// creativecommons.org/licenses/by/ $4.0 /)$.

\begin{abstract}
Numerous studies have investigated the relationship between income inequality and objective environmental pollution, but few focus on the nexus between income inequality and subjective environmental pollution (SEP). Using micro data from the Chinese General Society Survey (CGSS) in 2013 and official statistical data at the provincial level, this paper tests the impact of individual-level income inequality on subjective environmental pollution in China. The results show that individual-level income inequality has an inverted U-shape relationship with subjective environmental pollution, which indicates that increasing the income inequality at the individual level will first rise and then reduce their perceived subjective environmental pollution after reaching the peak. For about $84 \%$ of respondents, their subjective environmental pollution decreases with the increase of individual-level income inequality. Furthermore, the heterogeneity analyses show that the income inequality of urban residents and of the locals have an inverted U-shape effect on SEP, and the SEP of females and of individuals with positive environmental attitude are more sensitive to the effect of income inequality. Additionally, we find that subjective well-being plays a mediating role in the relation between income inequality and SEP. Individual income inequality decreases their self-reported well-being, and an increase in well-being has a negative effect on their subjectively perceived environmental quality. We also find non-television media exposures, such as newspaper, magazine, broadcasting, Internet, and mobile custom messages, will amplify the effect of individual-level income inequality on subjective environmental pollution.
\end{abstract}

Keywords: income inequality; relative deprivation in income; subjectively perceived environmental pollution; subjective well-being; media exposures

\section{Introduction}

Since China's reform and opening up in 1978, China has made great progress in economic development and poverty alleviation, but income inequality and environmental pollution issues followed. Income inequality and environmental pollution are very serious in China. Since 2000, income inequality in China has remained at a high level [1,2]. At the same time, environmental quality in China does not perform as well as economic development [3], especially air pollution and water pollution [4]. Therefore, it is necessary and urgent to research the tradeoff between income inequality and environmental pollution.

Existing papers have discussed the relationship between income inequality and environmental pollution [5-9], especially, the impact of income inequality on environmental pollution [10]. However, they mainly focused on the objective (actual) environmental pollution and ignored subjective (perceived) environmental pollution. The subjective environmental pollution, also called perceived environmental pollution [11], is measured by the respondents' cognitive evaluation on environmental quality [12,13]. Subjective environmental pollution has made the public worried and uncertain about the future risks and threatens the public's emotional and mental health [13]. Hence, the decrease in subjective environmental pollution has an important meaning for the public. 
The reason why inequality matters is that it emphasizes the extent to which individuals feel relatively deprived-that is, the gap where one stands relative to others [14,15]. Income inequality has an important impact on socioeconomic development. An increase in income inequality reduces the growth of economy [16], destroys the stability of society [17,18], and crowds out social trust [19]. Especially, income inequality has a negative correlation with individual physical health [20] and self-reported health [21-23]. The impacts of income inequality on socioeconomic outcomes have a negative effect on social welfare [24] and reduce the happiness and life satisfaction of residents [19,25-27], which results in the decline of subjective well-being $[28,29]$. The existing literature indicates that perceived subjective environmental pollution is not only affected by objective environmental pollution [30-33] but also by sociodemographic characteristics [32,34,35] and psychological factors [32,36]. Those declaring themselves unhappy generally tend to have more negative evaluation on perceived environmental pollution [31]. Based on those, we infer that subjective well-being possibly impacts the relationship between income inequality and subjective environmental pollution. Income inequality has a negative effect on subjective well-being, and an increase in subjective well-being reduces individual perceived SEP. Additional, mass media increase people's perceived environmental pollution and risk level [37]. Incomplete scientific information on the environment had the most impact on low-income households [38]. Hence, the nexus between income inequality and perceived environmental quality could be affected by mass media exposure.

To study the effect of individual income inequality on perceived subjective environmental pollution, we first measure individual income inequality; then, we combine individual information from CGSS with provincial socioeconomic and objective environment data from the National Bureau of Statistics of China (NBS) and Atmospheric Composition Analysis Group (ACAG). We use an ordered logistic regression model to identify the relationship and use other methods to test the robustness of the nexus. Finally, we discuss the possible mechanisms of individual income inequality on subjective environmental pollution from subjective well-being and media information exposure.

As a result, our main contributions for this paper are threefold. Firstly, from income deprivation, this paper analyzes, for the first time, the effect of income inequality on environmental pollution using individual-level data. Secondly, individuals' feelings are given full consideration in this paper. This paper focuses not only on the public's evaluation on environment but also on their feeling of relative deprivation in income. It assesses the relationship between income inequality and environmental pollution from the individual dimension and reveals how individuals with different levels of income inequality evaluate the environmental quality. Thirdly, this study, using China as the largest developing country, shows a nexus between individual income inequality and subjective environmental pollution and discusses the possible mechanisms of this effect. Income inequality and subjective environmental pollution impact individuals' happiness and the sustainability of economic development. Hence, it is very important for China's government to narrow income inequality and improve environmental quality.

Income inequality and environmental pollution have seriously threatened the sustainability of China's development. Especially, subjective environmental pollution decreases the residents' happiness and social welfare. As a result, for China's government and policy makers, it is very important and meaningful to gauge to what extent and how subjective environmental pollution is affected by individual income inequality. Understanding the nexus between subjective environmental pollution and individual income inequality is vital to assess and implement the redistribution policy in income.

\section{Literature Review}

Considerable studies have showed that economic growth has an inverted U-shape effect on income inequality [39] and environmental pollution [40,41]. Based on that, some scholars investigated the relationship between income inequality and objective environment pollution from four folds. 
A pioneering economist to study this topic is Boyce. He thought that the rich and powerful people benefited from environmental degradation and that the powerless and poor people bore the cost of environmental degradation. Therefore, he first proposed an "inequality hypothesis" that inequalities of power and wealth would lead to environmental degradation [42]. Based on the critical evaluation of the "inequality hypothesis", Scruggs (1998) [43] proposed that the rich had higher environmental concerns and preferred less environmental degradation than the poor and that inequality would improve environmental quality. Some scholars attempted to use marginal propensity emission (MPE) to explain the effect of income inequality on the environment [44-46]. When MPE fell as income rose, that is, the poor tended to have a higher MPE than the rich, increasing income inequality would improve environmental quality. If MPE increased with rising income, that is, the rich tended to have a higher MPE than the poor, declining income inequality would reduce environmental pollution [45]. Finally, some scholars used the "Veblen effect" to explain the effect of income inequality on environment $[44,46,47]$. Due to the "Veblen effect", work hours increased as income inequality rose [48]. Individuals in a given class preferred to compare themselves with the superior social class by emulating their consumption. Income inequality increased work hours and consumption, both of which would lead to environmental degradation [44,46,47,49].

Existing papers also examined the effect of income inequality on environmental pollution from experience. Some scholars found some cases in which income inequality measured by the Gini index deteriorated the environmental quality [50-52], improved the environmental quality [53], or had no impact on the environment [54] by using American data at the state level, Japanese data at the city level, or cross-country data. However, Chen et al., (2020), Baležentis et al., (2020), Grunewald et al., (2017), Jorgenson et al., (2017), and Uddin et al., (2020) $[7,44,46,47,49]$ used data at the country level. They found that the income inequality measured by Gini index had a non-linear effect on carbon emission. This effect was correlated with time, income level, and GDP per capita. There are also abundant studies examining the effect of income inequality on the environment in China. Using interprovincial data, the income gap measured by the Gini index increased carbon emission, and income inequality had a greater impact on carbon emission in eastern regions [55-57]. However, using data at the same level, some scholars found income inequality measured by the Gini index [5] and by the urban-rural income gap [58] had restricted the emission of pollutants and improved environmental quality.

In general, existing papers on the relationship between income inequality and the objective environment mainly employ macro data and cannot get consistent conclusions due to the differences among core indicators, the source, and the range of data. Until recently, Golley and Meng (2012) [59] used micro data from China's Urban Household Income and Expenditure Survey in 2005 and used MPE to explain the nexus between income inequality and the environment. They found that the rich households emitted more $\mathrm{CO}_{2}$ both directly and indirectly than the poor households, and they thought that income redistribution from the rich to the poor would lead to the decline of income inequality and $\mathrm{CO}_{2}$ emission in tandem. Hence, Chiarini et al., (2020) [31] referred to Jorgenson et al., (2017) [46] and used MPE to explain the relation between income inequality and perceived subjective environmental pollution. They found that a negative correlation existed between income inequality measured by the Gini index and perceived environmental quality in European countries. Higher income inequality meant a lower perceived environmental quality. Another possible reason was that income inequality may cause the poor to "select" residential areas with lower environmental quality [9]. Those respondents with lower income contributed less pollution but suffered more from pollution and thus reported a higher perceived environmental exposure [35].

Overall, although there have been some studies on the impacts of income inequality on environmental pollution, they mainly focused on income inequality at the group level, such as the Gini index [43,55,56,59], urban-rural income gap [58] or the income group in various deciles [59]. These studies ignored the effect of income inequality at the individual 
level on environmental pollution. Additionally, the existing papers mainly investigated objective environmental issues-carbon emission, haze, etc. The studies in the literature on the nexus between individual income inequality and subjective environmental quality are relatively scare. In addition, existing papers mainly provided the experiences on the effect of income inequality on subjective environmental quality in European countries [31]. As such, this study fills the academic gap and contributes to the literature by quantitatively exploring, for the first time, the effect and mechanism of individual income inequality on subjective environmental pollution on the basis of China's individual-level data.

\section{Materials and Methodology}

\subsection{Data}

The individual-level information, including subjective environmental pollution and socioeconomic characteristics, is collected from the 2013 waves of CGSS. CGSS is jointly conducted by Renmin University of China and the Hong Kong University of Science and Technology since 2003, covering rural and urban areas. CGSS 2013 covers 11438 observations in 28 mainland provincial administrative units (excluding Tibet, Xinjiang, Hainan, Taiwan, Hong Kong, and Macao). The final analysis sample includes 7314 observations after eliminating the missing values for the studied variables. We also use socioeconomic indicators and objective environmental pollution from the China Statistical Yearbook published by the NBS and ACAG in 2013 to control provincial characteristics.

\subsubsection{Subjective Environmental Pollution}

The survey of CGSS 2013 contains 12 questions covering air, water, noise, garbage, vegetation, food, desertification, biodiversity, etc. to measure the respondents' subjective evaluation on environmental quality. The scores of these relating variables from 1 to 7 stand for "very serious" to "no problem", where 1 denotes "very serious", 2 stands for "somewhat serious", 3 is "not very serious", 4 denotes "not serious", 5 indicates "indifferent", 6 denotes "no concern/unclear", and 7 is "no problem". To reflect environmental pollution more directly, we reassign the value and combine item 6 and item 7 . We employ that 0 denotes "this problem does not exist", 1 stands for "indifferent", 2 indicates "not serious", 3 is "not very serious", 4 is "somewhat serious", and 5 stands for "very serious". The larger the value, the worse the subjective environmental quality. The first five questions-air pollution, water pollution, noise pollution, industrial waste pollution, and garbage pollution - measure pollution that affect human health and safety, and the remaining seven questions measure the severity of environmental degradation. Therefore, we mainly use the first five questions (How serious is the air pollution/water pollution/noise pollution/industrial waste pollution/garbage pollution problem in your area?) to measure subjective environmental pollution (SEP). The SEP is measured by the arithmetic mean of the five environmental variables.

\subsubsection{Income Inequality}

Referring to $[15,23,60]$, we employ relative deprivation in income (RD) to measure individuals' income inequality. This paper employs the Yitzhaki index and Kakwani index to measure relative deprivation in income. The previous literature shows that the Yitzhaki index as follows: Yitzhaki index $x_{i}=\frac{\sum\left(y_{j}-y_{i}\right)}{n}$ for all $y_{j}>y_{i}$, where $y_{i}$ is the income of individual $i$ [61]. The index (Yitzhaki index is standardized, and a one-unit increase of Yitzhkai index means an increase of one standard deviation [14]. The Yitzhkai index is sensitive to the scale of income; it is not appropriate in panel data [62]. Considering that we use cross-sectional data, the challenge will not be taken into consideration) equals the sum of the difference of income between individual $i$ and others who are higher than individual $i$ and then divided by the size of reference group $(n)$. We use the Kakwani index in our robustness test. The Kakwani index is the Yitzhaki index divided by the mean income of the reference group (Kakwani index $x_{i}=\frac{\sum\left(y_{j}-y_{i}\right)}{n \bar{y}}$, for all $y_{j}>y_{i}$, where $\bar{y}$ is the mean income of the reference group). Referring to Jones and Wildman (2008) [63], we use a national 
reference group. The larger the Yitzhaki index and Kakwani index of the individual $i$, the more unequal to individual $i$. The value of the Yitzhaki index is more than zero, and the range of the Kakwani index is from zero to one. (The mean of the Kakwani index for an individual in the reference group is equal to the Gini coefficient of the reference group [62], and the mean of the Yitzhaki index for individuals in the reference group is the mean income multiplied by the Gini coefficient of the reference group [14]).

Some househusbands and housewives have no income, but their spouses may have higher income, and some families have higher income because of the larger scale of family. Therefore, we use income inequality calculated by individual income (Individual income is related to the question, "What was your personal total income last year (2012)?"), household income (Household income is related to the question, "What was your family's total annual income in 2012?") and household income per capita (Household income per capita equals the total household income divided by household size that is measured by the number of family members), considering that different income only represents one aspect of the respondents in income inequality. Yitzhaki and Kakwani denote the Yitzhaki index and Kakwani index, respectively. $i n_{i}, i n_{h}$, and $i n_{p}$ represent individual income, household income, and household income per capita, respectively. $r_{a}$ denotes that the reference group includes all respondents in our sample, and $r_{s}$ indicates that the reference group only includes individuals that have non-zero income. The larger the mean and standard error of the Yitzhaki index, the higher the volatility of the Yitzhaki index. We will take the logarithm of the Yitzhaki in our study to reduce heteroskedasticity. The Kakwani index has a relatively smaller mean and standard error; we will directly use Kakwani in our empirical model. We use the Yitzhaki $i_{i} r_{a}$ index as the main measure of income inequality and the other seven indicators as alternative measures for robustness checks.

\subsubsection{Control Variables}

This paper also controls environmental behavior (env behavior) (The behavior of environment is related to question, "Have you actively participated in complaints and appeals for environmental issues in the past year?", and the response that 1 is often, 2 is occasionally, and 3 denotes always), environmental knowledge (env know) (The knowledge of environment is related to 10 items of the respondents' grasp of knowledge on environmental protection. If the respondent answers right, he/she gets one score; otherwise, he/she gets zero score. Then, we sum the score of each item of each respondent and get the score of the respondent's environmental knowledge), gender (gender), environmental attitude (env attitude) (Environmental attitude is a dummy variable, which is related to the questions, "What do you think is the most important problem to be solved in the following social issues?". If the respondent places environmental issue as one of the first three problems needed to be solved, the value takes one; otherwise, it takes zero), cognitive ability (ind cog) (Individual cognitive ability is related to questions, "Which level do you think you have the listening ability in Mandarin/English?" and "Which level do you think you have the speaking ability in Mandarin/English?". The score of the four questions is from 1 to 5 , where 1 denotes that the respondent cannot understand by listening or cannot speak the language at all, and 5 means that the respondent is excellent in each ability. We take the mean value of the score of the four abilities), health (health) (Health is related the question, "What do you think is your status of current physical health?". The score ranges from 1 to 5, and the higher the score, the better the status of physical health), well-being (well-being) (Well-being is related to the question, "In general, do you feel happy in your life?" The score ranges from 1 to 5, and the higher the score, the happier life), migrant or not (migrant), and household income per capita (lnphi) at the individual level, and the paper controls economic growth, population, and pollution at the provincial level. To reduce heteroskedasticity, we take the logarithm of household income per capita and the logarithm of control variables at the provincial level. Control variables at the provincial level include the logarithms of GDP per capita (lnPGDP) and its square term (lnPGDP2), population density (pop den), the concentration of $\mathrm{PM}_{2.5}\left(\mathrm{pm}_{2.5}\right)$, the quantity of household 
refuse (garbage), the emission of smoke (smoke), the emission of $\mathrm{SO}_{2}$ (so2), the emission of nitrogen oxides (nox), and the discharge of waste water (wat poll). $\mathrm{PM}_{2.5}$ data are from ACAG, and other control variables at the provincial level are from NBS. Table 1 displays the descriptive statistics of control variables.

Table 1. Descriptive statistics of variables.

\begin{tabular}{|c|c|c|c|c|c|}
\hline & Obs. & Mean & sd & Min & Max \\
\hline Air pollution & 7314 & 2.74 & 1.64 & 0.000 & 5.000 \\
\hline Water pollution & 7314 & 2.65 & 1.63 & 0.000 & 5.000 \\
\hline Noise pollution & 7314 & 2.44 & 1.64 & 0.000 & 5.000 \\
\hline Industrial pollution & 7314 & 2.10 & 1.72 & 0.000 & 5.000 \\
\hline Garbage pollution & 7314 & 2.66 & 1.57 & 0.000 & 5.000 \\
\hline SEP & 7314 & 2.52 & 1.30 & 0.000 & 5.000 \\
\hline Yitzhaki $i_{i n_{i} r_{a}}$ & 7314 & $12,761.41$ & 6936.68 & 82.983 & $23,814.436$ \\
\hline Yitzhaki $_{\text {in }_{i} r_{s}}$ & 6556 & $12,965.74$ & 6952.87 & 93.695 & $26,808.352$ \\
\hline Yitzhaki $_{i n_{h} r_{s}}$ & 6835 & $27,689.21$ & $13,874.85$ & 0.000 & $58,454.809$ \\
\hline Yitzhaki ${ }_{i n_{p} r_{s}}$ & 6835 & $10,386.36$ & 4551.01 & 0.000 & $19,786.146$ \\
\hline Kakwani $_{i n_{i} r_{a}}$ & 7314 & 0.54 & 0.29 & 0.003 & 1.000 \\
\hline Kakwani $_{i n_{i} r_{s}}$ & 6556 & 0.48 & 0.26 & 0.003 & 0.997 \\
\hline Kakwani $_{i n_{h} r_{s}}$ & 6835 & 0.47 & 0.24 & 0.000 & 0.992 \\
\hline Kakwani $_{\text {in }_{p} r_{s}}$ & 6835 & 0.52 & 0.23 & 0.000 & 0.992 \\
\hline env behavior & 7308 & 1.11 & 0.35 & 1.000 & 3.000 \\
\hline env know & 7314 & 5.30 & 2.70 & 0.000 & 10.000 \\
\hline gender & 7314 & 0.54 & 0.50 & 0.000 & 1.000 \\
\hline env attitude & 7314 & 0.30 & 0.73 & 0.000 & 3.000 \\
\hline ind cong & 7314 & 2.56 & 0.71 & 1.000 & 5.000 \\
\hline health & 7313 & 3.82 & 1.03 & 1.000 & 5.000 \\
\hline well-being & 7314 & 3.80 & 0.81 & 1.000 & 5.000 \\
\hline migrant & 7310 & 0.28 & 0.45 & 0.000 & 1.000 \\
\hline lnphi & 6835 & 9.43 & 1.02 & 5.116 & 16.118 \\
\hline $\operatorname{lnPGDP}$ & 7314 & 10.78 & 0.42 & 10.050 & 11.514 \\
\hline lnPGDP2 & 7314 & 116.32 & 9.10 & 100.998 & 132.572 \\
\hline pop den & 7314 & 7.89 & 0.41 & 6.965 & 8.620 \\
\hline pm25 & 7314 & 3.71 & 0.45 & 2.537 & 4.426 \\
\hline garbage & 7314 & 6.34 & 0.58 & 4.305 & 7.646 \\
\hline nox & 7314 & 4.18 & 0.59 & 2.582 & 5.107 \\
\hline so2 & 7314 & 4.04 & 0.71 & 2.163 & 5.103 \\
\hline wat poll & 7314 & 12.29 & 0.66 & 9.997 & 13.668 \\
\hline smoke & 7314 & 3.49 & 0.77 & 1.780 & 4.878 \\
\hline
\end{tabular}

Note: the unit of Yitzhaki is Yuan, pop den, pm25, garbage, nox, so2, wat poll, and smoke are taken as a logarithm.

\subsection{Empirical Method}

Since the dependent variable, subjective environmental pollution, is divided into point grades from 0 to 5 , belonging to ordered qualitative variables, we mainly use the ordered logit model to analyze the impact of individual-level income inequality on subjective environmental pollution [64], and we employ an ordinary least square (OLS) and ordered probit model for a robustness check. Under the framework of EKC theory, Chen et al., (2020), Baležentis et al., (2020), Grunewald et al., (2017), Jorgenson et al., (2017), Uddin et al., (2020), and Wu and Xie (2020) $[7,44,46,47,49,65]$ found that a non-linear nexus exists between income inequality and environment. Therefore, we set the basic model as follows:

$$
\text { pollution }_{i}=\alpha_{0}+\alpha_{1} \text { inequality }_{i}+\alpha_{2} \text { inequality }_{i}^{2}+X^{\prime} \gamma+\epsilon_{i}
$$

where $i$ is respondent $i, \epsilon$ denotes error term, $\alpha$ and $\gamma$ are the estimation coefficients, and pollution measures the subjective environmental pollution. inequality represents individual income inequality, and inequality ${ }^{2}$ denotes the square of individual income inequality. $X$ represents the control variables, including individual characteristics and provincial factors. Therefore, the coefficients of interest, $\alpha_{1}$ and $\alpha_{2}$, denote the effect on 
individual-level income inequality on subjective environmental pollution. The signs of $\alpha_{1}$ and $\alpha_{2}$ show the shape between individual-level income inequality and subjective environmental pollution.

After determining the estimation methods, it is necessary to conduct diagnostic tests of the models. Firstly, we conduct tests of the Pearson correlation coefficient (see Table A1, Appendix A). The correlation coefficients are above 0.9 for some variables. Hence, there might be multicollinearity between dependent variables. It could decrease the statistical significance of our results. Secondly, we judge the number of explanatory variables by using information criteria (see Table A2). The model including individual characteristics and city factors is a better model. Thirdly, we conduct Ramsey RESET tests to test whether there exist omitted variables (see Table A3). The results show that there exist omitted variables in our three models, but the omitted information in the model that controls individual and city factors is fewer. Based on those, we conduct robustness tests to prove the robustness of the effect of income inequality on subjective environmental pollution. We mainly illustrate the results in the models that include both individual characteristics and city factors.

\subsection{Mechanism Analysis}

Referring to Baron and Kenny (1986) [66], we set models as follows and use a causal step approach to estimate the role of subjective well-being in the nexus between individual income inequality and subjective environmental pollution:

$$
\begin{aligned}
& \text { pollution }_{i}=\alpha_{0}+\alpha_{1} \text { inequality }_{i}+\alpha_{2} \text { inequality }_{i}^{2}+X_{1}^{\prime} \gamma_{1}+\epsilon_{1 i} \\
& \text { well }- \text { being }_{i}=\beta_{0}+\beta_{1} \text { inequality }_{i}+X_{2}^{\prime}+\epsilon_{2 i} \\
& \text { pollution }_{i}=\alpha_{0}^{\prime}+\alpha_{1}^{\prime} \text { inequality }_{i}+\alpha_{2}^{\prime} \text { inequality }_{i}^{2}+\alpha_{3}^{\prime}\left(\text { well }- \text { being }_{i}\right)+X_{1}^{\prime} \gamma_{1}+\epsilon_{3 i}
\end{aligned}
$$

where $\alpha_{1}$ and $\alpha_{2}$ in Equation (2) denote the total effect of income inequality on subjective environmental pollution, $\beta_{1}$ denotes the effect of income inequality on subjective well-being, and $\alpha_{1}^{\prime}$ and $\alpha_{2}^{\prime}$ denotes the direct effect of income inequality on subjective environmental pollution. The indirect effect of subjective well-being on subjective environmental pollution is the product of $\beta_{1}$ and $\alpha_{3}^{\prime}$. If $\beta_{1}$ and $\alpha_{3}^{\prime}$ are statistically significant, it means that subjective well-being plays a mediating role in the relationship between income inequality and subjective environmental pollution. $X$ is the control variables, and $\varepsilon$ denotes error term. The subscript, Arabic numerals, differentiates the differences in each model.

In general, the individuals that suffer from more income inequality use less media than others (see Table A4). Meanwhile, the individuals exposed to more media have more awareness and behavior of environmental pollution [37,67]. It might raise a question of which mass media exposure can play a moderating role in the effect of income inequality on subjective environmental pollution. Hence, we refer to Baron and Kenny (1986) [66] to construct Equation (5) and discuss the effect of the mass media exposure on the nexus between income inequality and subjective environmental pollution.

$$
\text { pollution }_{i}=\alpha_{0}+\alpha_{1} \text { inequality }_{i}+\alpha_{2} \text { inequality }_{i}^{2}+\alpha_{3} \text { media }_{i}+\alpha_{4} \text { inequality }_{i} * \text { media }_{i}+X^{\prime} \gamma+\epsilon_{i}
$$

where $\alpha_{4}$ denotes the effect of income inequality on subjective environmental pollution as the change of media exposures, and other variables have the same definition as above. Media are related to question, "In the past year, your usage of the following media is", where 1 denotes never, 2 is rarely, 3 presents sometimes, 4 is often, and 5 means very regularly. Media include magazines, newspapers, broadcasting, television, Internet (including surfing the Internet with a mobile phone), and mobile custom messages. 


\section{Results}

\subsection{Baseline Results}

We estimate the effect of income inequality on SEP by using Equation (1) and present the results in Table 2. The results in columns (1)-(3) are estimated using the OLS model, and columns (4)-(6) are the estimation results of an ordered logit model.

Table 2. The effect of individual-level income inequality on subjective environmental pollution: baseline results.

\begin{tabular}{|c|c|c|c|c|c|c|}
\hline & (1) & (2) & (3) & (4) & (5) & (6) \\
\hline & \multicolumn{3}{|c|}{ OLS } & \multicolumn{3}{|c|}{ Ordered logit model } \\
\hline inequality & $\begin{array}{c}1.546^{* * *} \\
(5.65)\end{array}$ & $\begin{array}{c}1.328^{* * *} \\
(4.66)\end{array}$ & $\begin{array}{c}0.886^{* * * *} \\
(3.16)\end{array}$ & $\begin{array}{c}2.036^{* * *} \\
(5.29)\end{array}$ & $\begin{array}{c}1.904^{* * *} \\
(4.68)\end{array}$ & $\begin{array}{c}1.317^{* * *} \\
(3.20)\end{array}$ \\
\hline inequality $^{2}$ & $\begin{array}{c}-0.109 \text { *** } \\
(-7.00)\end{array}$ & $\begin{array}{c}-0.079 * * * \\
(-4.83)\end{array}$ & $\begin{array}{c}-0.053^{* * *} \\
(-3.27)\end{array}$ & $\begin{array}{c}-0.144^{* * *} \\
(-6.58)\end{array}$ & $\begin{array}{c}-0.113^{* * *} \\
(-4.83)\end{array}$ & $\begin{array}{c}-0.077^{* * *} \\
(-3.25)\end{array}$ \\
\hline lnphi & & $\begin{array}{c}0.176^{* * *} \\
(7.46)\end{array}$ & $\begin{array}{c}0.110^{* * *} \\
(4.73)\end{array}$ & & $\begin{array}{c}0.259^{* * *} \\
(7.60)\end{array}$ & $\begin{array}{c}0.165^{* * *} \\
(4.85)\end{array}$ \\
\hline $\begin{array}{c}\text { env } \\
\text { behavior }\end{array}$ & & $0.296^{* * *}$ & $0.286^{* * *}$ & & $0.439^{* * *}$ & $0.451^{* * *}$ \\
\hline & & $(6.96)$ & $(6.78)$ & & $(6.71)$ & $(6.62)$ \\
\hline env know & & $\begin{array}{c}0.048^{* * *} \\
(7.36)\end{array}$ & $\begin{array}{c}0.049^{* * *} \\
(7.70)\end{array}$ & & $\begin{array}{c}0.063^{* * *} \\
(6.69)\end{array}$ & $\begin{array}{c}0.070^{* * *} \\
(7.49)\end{array}$ \\
\hline gender & & $\begin{array}{c}-0.080 \text { ** } \\
(-2.44)\end{array}$ & $\begin{array}{l}-0.061 * \\
(-1.92)\end{array}$ & & $\begin{array}{c}-0.110 * * \\
(-2.36)\end{array}$ & $\begin{array}{l}-0.078 * \\
(-1.69)\end{array}$ \\
\hline $\begin{array}{c}\text { env } \\
\text { attitude }\end{array}$ & & $0.074^{* * *}$ & $0.065^{* * *}$ & & $0.093^{* * *}$ & $0.087^{* * *}$ \\
\hline & & $(3.89)$ & $(3.40)$ & & $(3.40)$ & $(3.07)$ \\
\hline ind cong & & $\begin{array}{c}0.191^{* * *} \\
(7.61)\end{array}$ & $\begin{array}{c}0.147^{* * *} \\
(5.91)\end{array}$ & & $\begin{array}{c}0.278^{* * *} \\
(7.54)\end{array}$ & $\begin{array}{c}0.223^{* * *} \\
(5.97)\end{array}$ \\
\hline health & & $\begin{array}{l}-0.007 \\
(-0.43)\end{array}$ & $\begin{array}{l}-0.003 \\
(-0.18)\end{array}$ & & $\begin{array}{l}-0.008 \\
(-0.38)\end{array}$ & $\begin{array}{l}-0.005 \\
(-0.23)\end{array}$ \\
\hline well-being & & $\begin{array}{c}-0.132^{* * *} \\
(-6.83)\end{array}$ & $\begin{array}{c}-0.111^{* * *} \\
(-5.82)\end{array}$ & & $\begin{array}{c}-0.194^{* * *} \\
(-6.90)\end{array}$ & $\begin{array}{c}-0.168^{* * *} \\
(-5.85)\end{array}$ \\
\hline $\ln P G D P$ & & & $\begin{array}{l}-4.924 \text { * } \\
(-1.66)\end{array}$ & & & $\begin{array}{l}-6.250 \\
(-1.47)\end{array}$ \\
\hline $\operatorname{lnPGDP2}$ & & & $\begin{array}{l}0.248 * \\
(1.79)\end{array}$ & & & $\begin{array}{l}0.316 \\
(1.59)\end{array}$ \\
\hline pop den & & & $\begin{array}{l}0.034 \\
(0.82)\end{array}$ & & & $\begin{array}{l}0.055 \\
(0.90)\end{array}$ \\
\hline pm25 & & & $\begin{array}{c}0.394^{* * *} \\
(8.68)\end{array}$ & & & $\begin{array}{c}0.573^{* * *} \\
(8.63)\end{array}$ \\
\hline garbage & & & $\begin{array}{c}0.562 * * * \\
(8.79)\end{array}$ & & & $\begin{array}{c}0.833^{* * *} \\
(8.79)\end{array}$ \\
\hline nox & & & $\begin{array}{c}-0.368^{* * *} \\
(-3.18)\end{array}$ & & & $\begin{array}{c}-0.463^{* * *} \\
(-2.76)\end{array}$ \\
\hline so2 & & & $\begin{array}{c}0.255^{* * *} \\
(3.79)\end{array}$ & & & $\begin{array}{c}0.305^{* * *} \\
(3.05)\end{array}$ \\
\hline wat poll & & & $\begin{array}{c}-0.666^{* * *} \\
(-10.07)\end{array}$ & & & $\begin{array}{c}-0.990 \text { *** } \\
(-10.39)\end{array}$ \\
\hline smoke & & & $\begin{array}{c}0.150 * \\
(1.87)\end{array}$ & & & $\begin{array}{l}0.186 \\
(1.55)\end{array}$ \\
\hline $\mathrm{N}$ & 7314 & 6825 & 6825 & 7314 & 6825 & 6825 \\
\hline
\end{tabular}

Notes: The parentheses show $t$ value of robust standard error. Asterisks indicate the statistical significance, where $* * *$, and ${ }^{* * *}$ denote significance at $10 \%, 5 \%$, and $1 \%$ levels, respectively.

The linear and quadratic coefficients of inequality are significantly positive and negative at the $1 \%$ level, respectively, showing an inverted U-shape relationship between income inequality and subjective environmental quality. The turning point of income inequality is 
around 8.4, which indicates that the subjective environmental pollution of approximately $84 \%$ of respondents increases with the decrease of individual-level income inequality.

In conclusion, there exists an inverted U-shape relationship between individual-level income inequality and subjective environmental pollution, among which approximate $84 \%$ of respondents' subjective environmental pollution decreases with the increase of income inequality. With the increase of income inequality at an individual level, subjective evaluation on environmental pollution is first getting worse and then getting better after reaching the peak.

\subsection{Robustness Test}

\subsubsection{Regression for Different Subjective Environmental Pollution}

We use the five subjective environmental pollution indicators: air pollution, water pollution, noise pollution, industrial waste pollution, and garbage pollution, as dependent variables to analyze the effect of individual-level income inequality on different subjective environmental pollution. The results are reported in Table 3.

Table 3. The effect of individual-level income inequality on different subjective environmental pollution.

\begin{tabular}{|c|c|c|c|c|c|}
\hline & (1) & (2) & (3) & (4) & (5) \\
\hline & Air pollution & Water pollution & Noise pollution & $\begin{array}{l}\text { Industrial waste } \\
\text { pollution }\end{array}$ & Garbage pollution \\
\hline inequality & $\begin{array}{l}1.252^{* * *} \\
(2.79)\end{array}$ & $\begin{array}{l}0.945^{* *} \\
(2.32)\end{array}$ & $\begin{array}{l}1.973 * * * \\
(4.77)\end{array}$ & $\begin{array}{c}0.752 * \\
(1.71)\end{array}$ & $\begin{array}{l}0.819 * \\
(1.90)\end{array}$ \\
\hline inequality $^{2}$ & $\begin{array}{c}-0.074^{* * *} \\
(-2.86)\end{array}$ & $\begin{array}{c}-0.056 * * \\
(-2.40)\end{array}$ & $\begin{array}{c}-0.118^{* * *} \\
(-4.95)\end{array}$ & $\begin{array}{l}-0.044 * \\
(-1.75)\end{array}$ & $\begin{array}{l}-0.043 * \\
(-1.72)\end{array}$ \\
\hline Individual factors fixed effect & Yes & Yes & Yes & Yes & Yes \\
\hline Provincial factors fixed effect & Yes & Yes & Yes & Yes & Yes \\
\hline $\mathrm{N}$ & 6825 & 6825 & 6825 & 6825 & 6825 \\
\hline
\end{tabular}

Notes: The parentheses show the $t$ value of robust standard error. Asterisks indicate the statistical significance, where ${ }^{*}, * *$ and ${ }^{* * *}$ denote significance at the $10 \%, 5 \%$, and $1 \%$ levels, respectively. The results are estimated by an ordered logit model.

Similar to the results in Table 2, the linear coefficients of inequality (inequality) are significantly positive at the $10 \%$ level and the quadratic coefficients of inequality (inequality ${ }^{2}$ ) are negative at the $5 \%$ significance level, which support there being an inverted U-shape relation between income inequality at an individual level and subjective environmental pollution. Similar to subjective environmental pollution, the turning point of income inequality for subjective air/water/noise/industrial waste pollution is around 8.5, but the turning point for subjective garbage pollution is larger than 8.5. The results show for over $84 \%$ of respondents that their subjective air, water, noise, and industrial waste pollution are negatively correlated with income inequality, but that only $38.8 \%$ of respondents' subjective garbage pollution decreases following the increase of income inequality. The signs of coefficients of the control variables are the same as the results in Table 2, which shows that the estimation results are robust.

Therefore, individual-level income inequality has a robust inverted U-shape effect on subjective environmental pollution.

\subsubsection{Regression for Other Income Inequality Indicators}

This part measures income inequality employing other methods to test the robustness of the effect of individual-level income inequality on subjective environmental pollution. The results are reported in Table 4 . The coefficients of linear inequality (inequality) are positive, and the coefficients of quadratic inequality (inequality ${ }^{2}$ ) are significantly negative. It supports that an inverted U-shape relationship exists between income inequality and subjective environmental pollution. 
Table 4. The effect of individual-level income inequality on subjective environmental pollution: robustness test based on different measurements of income inequality at in individual level.

\begin{tabular}{|c|c|c|c|c|c|c|c|}
\hline & (1) & (2) & (3) & (4) & (5) & (6) & (7) \\
\hline & Yitzhaki $i_{i n_{i} r_{s}}$ & Yitzhaki $_{i n_{h} r_{s}}$ & Yitzhaki $_{i n_{p} r_{s}}$ & Kakwani $_{i n_{i} r_{a}}$ & Kakwani ${ }_{i n_{i} r_{s}}$ & Kakwani $_{i n_{h i} r_{s}}$ & Kakwani $i_{\text {in }} r_{s}$ \\
\hline inequality & $\begin{array}{c}1.784^{* * *} \\
(3.84)\end{array}$ & $\begin{array}{c}1.835^{* *} \\
(2.08)\end{array}$ & $\begin{array}{c}6.231^{* * *} \\
(4.38)\end{array}$ & $\begin{array}{l}0.435 \\
(1.13)\end{array}$ & $\begin{array}{c}1.400 * * * \\
(3.35)\end{array}$ & $\begin{array}{c}1.119 * * * \\
(2.59)\end{array}$ & $\begin{array}{l}0.121 \\
(0.21)\end{array}$ \\
\hline inequality $^{2}$ & $\begin{array}{c}-0.103^{* * *} \\
(-3.84)\end{array}$ & $\begin{array}{l}-0.086 * \\
(-1.86)\end{array}$ & $\begin{array}{c}-0.362 * * * \\
(-4.27)\end{array}$ & $\begin{array}{l}-0.597 * \\
(-1.91)\end{array}$ & $\begin{array}{c}-1.780 * * * \\
(-4.75)\end{array}$ & $\begin{array}{c}-0.910 * * \\
(-2.34)\end{array}$ & $\begin{array}{c}-1.601 * * * \\
(-3.63)\end{array}$ \\
\hline Individual factors fixed effect & Yes & Yes & Yes & Yes & Yes & Yes & Yes \\
\hline Provincial factors fixed effect & Yes & Yes & Yes & Yes & Yes & Yes & Yes \\
\hline $\mathrm{N}$ & 6211 & 6825 & 6825 & 6826 & 6212 & 6826 & 6826 \\
\hline
\end{tabular}

Notes: Asterisks indicate the statistical significance, where ${ }^{* * *}, * *$, and ${ }^{*}$ represent significance at $1 \%, 5 \%$, and $10 \%$ levels, respectively. The parentheses show the $t$ value of robust standard error. The results in this table are estimated by an ordered logit model. N is the number of observations.

\subsubsection{Regression for Other Methods}

Considering that heteroscedasticity possibly exists among different groups, we report the clustered robust standard errors in columns (1)-(3) in Table 5. The standard error in columns (1)-(3) are clustered at province, city, and county levels, respectively. Additionally, the results in column 4 in Table 5 are estimated by ordered probit model. The results on inequality (inequality) and its quadratic term (inequality ${ }^{2}$ ) are similar to the baseline results. It supports that an inverted U-shape relationship exists between individual-level income inequality and subjective environmental pollution.

Table 5. The effect of individual-level income inequality on subjective environmental pollution: robustness test based on cluster analysis and ordered probit model.

\begin{tabular}{ccccc}
\hline & $\mathbf{( 1 )}$ & $\mathbf{( 2 )}$ & $\mathbf{( 3 )}$ & $\mathbf{( 4 )}$ \\
\hline & clustered at province level & clustered at city level & clustered at county level & probit \\
\hline inequality & $1.317^{* *}$ & $1.317^{* *}$ & $1.317^{* *}$ & $(2.53)$ \\
inequality & $(2.39)$ & $(2.46)$ & $-0.737^{* * *}$ & $(3.11)$ \\
& $-0.077^{* *}$ & $(-2.41)$ & $-0.077^{* * *}$ & $-0.043^{* * *}$ \\
\hline Individual factors fixed effect & $(-2.36)$ & Yes & $(-2.59)$ & $(-3.17)$ \\
Provincial factors fixed effect & Yes & Yes & Yes & Yes \\
$\mathrm{N}$ & 6825 & 6825 & 6825 & Yes \\
\hline
\end{tabular}

Note: The parentheses show $t$ statistics, where columns 1-3 are $t$ values of clustering robust standard error. Asterisks indicates the statistical significance, where ${ }^{* * *}$ and ${ }^{* *}$ represent significance at $1 \%$ and $5 \%$ levels, respectively. Column 1 indicates clusters at the province level, column 2 indicates clusters at the city level, column 3 indicates clusters at the county level. Column 4 is estimated by an ordered probit model. $\mathrm{N}$ is the number of observations.

Consequently, individual-level income inequality has a robust inverted U-shape effect on subjective environmental pollution. With the increase of income inequality, subjective environmental pollution is first getting worse and then getting better.

\section{Discussion}

Increasing individual-level income inequality first increases and then decreases subjective environmental pollution. However, there also exist heterogenous effects of individuallevel income inequality on subjective environmental pollution, due to the differences of income inequality and subjective environmental pollution among various groups. In the following analysis, we will discuss the different effects of income inequality on subjective environmental pollution in various contexts.

\subsection{Difference between the Urban and Rural Residents}

According to the living places of the respondents, the samples are divided into the urban area group and rural area group (If the respondents live in a rural area, they are 
classified into the rural area group; otherwise, they are in the urban area group. The urban area group includes the respondents living in the central area, suburban fringe, rural-urban fringe zone of the city or county, and in the town outside of the city or county). The respondents living in the rural area have higher income inequality and have better evaluations on environmental quality than those living in the urban area (see Table 6). Further investigation finds that the coefficients of linear inequality (inequality) and its quadratic term (inequality ${ }^{2}$ ) are not significant in the rural area (in columns 4-6 in Table 7), but that the coefficients of linear (inequality) and square inequality (inequality ${ }^{2}$ ) in the urban area are significantly negative and positive at the $1 \%$ level (see columns 1-3 in Table 7), respectively. It indicates that individual-level income inequality has an inverted U-shape effect on subjective environmental pollution in the urban area group, among which approximately $71 \%$ of respondents' subjective environmental pollution decreases following the increase of income inequality.

Table 6. $t$ test of individual-level income inequality and subjective environmental pollution: differences in the urban and rural area.

\begin{tabular}{ccccccc}
\hline & \multicolumn{2}{c}{ The Urban Area } & \multicolumn{2}{c}{ The Rural Area } & \multirow{2}{*}{ Diff. } & \multirow{2}{*}{$\boldsymbol{t}$} \\
\cline { 1 - 4 } & Mean & Obs. & Mean & Obs. & & \\
\hline inequality $^{\text {inequality }}{ }^{2}$ & 9.061 & 4761 & 9.606 & 2550 & $-0.545^{* * *}$ & -32.936 \\
SEP & 82.659 & 4761 & 92.545 & 2550 & $-9.886^{* * *}$ & -33.990 \\
& 3.146 & 4761 & 2.364 & 2551 & $0.782^{* * *}$ & 25.280
\end{tabular}

Note: Diff. denotes the differences of mean value between the urban area group and rural area group, $t$ is $t$ statistics. Asterisks indicate the statistical significance, where ${ }^{* * *}$ denotes significance at the $1 \%$ level.

Table 7. The effect of individual-level income inequality on subjective environmental pollution: differences in the urban and rural area.

\begin{tabular}{|c|c|c|c|c|c|c|}
\hline & (1) & (2) & (3) & (4) & (5) & (6) \\
\hline & \multicolumn{3}{|c|}{ The urban area } & \multicolumn{3}{|c|}{ The rural area } \\
\hline inequality & $\begin{array}{c}0.982 * * \\
(2.43)\end{array}$ & $\begin{array}{c}1.219 * * * \\
(2.93)\end{array}$ & $\begin{array}{c}0.931^{* *} \\
(2.24)\end{array}$ & $\begin{array}{l}-1.029 \\
(-1.27)\end{array}$ & $\begin{array}{l}-1.330 \\
(-1.58)\end{array}$ & $\begin{array}{l}-1.329 \\
(-1.31)\end{array}$ \\
\hline inequality $^{2}$ & $\begin{array}{c}-0.069 * * * \\
(-2.94)\end{array}$ & $\begin{array}{c}-0.071^{* * *} \\
(-2.90)\end{array}$ & $\begin{array}{c}-0.053^{* *} \\
(-2.18)\end{array}$ & $\begin{array}{l}0.040 \\
(0.90)\end{array}$ & $\begin{array}{l}0.067 \\
(1.41)\end{array}$ & $\begin{array}{l}0.068 \\
(1.20)\end{array}$ \\
\hline Individual factors fixed effect & No & Yes & Yes & No & Yes & Yes \\
\hline Provincial factors fixed effect & No & No & Yes & No & No & Yes \\
\hline $\mathrm{N}$ & 4761 & 4457 & 4457 & 2550 & 2368 & 2368 \\
\hline
\end{tabular}

Notes: The parentheses show $t$ value of robust standard error. Asterisks indicate the statistical significance, where ${ }^{* *}$ and ${ }^{* * *}$ denote significance at the $5 \%$ and $1 \%$ levels, respectively. The results in this table are estimated by an ordered logit model. $\mathrm{N}$ is the number of observations.

Therefore, individual-level income inequality has an inverted U-shape relationship with subjective environmental pollution for the urban residents and has little impact on the subjective environmental pollution for the rural residents.

\subsection{The Differences between the Local and Migrants}

We define a migrant as one whose hukou is not the same place as their habitation or he/she changed the registered address of their hukou (If the hukou of the respondent is outside of the district, county, and county-level city, the respondent migrates to the locality, or the hukou is not in the locality but he/she lives in the locality, we define these respondents as migrants; otherwise, we define them as the local people). Based on that, the samples are classified into locals and migrants. Migrants have lower income inequality and have worse evaluation on environment quality compared with the locals (see Table 8). We further report the estimation results in Table 9. The coefficients of linear inequality (inequality) are positive, and those of its square term (inequality ${ }^{2}$ ) are negative. The results of the locals are significant at the $1 \%$ level but those of migrants are not significant at the $10 \%$ 
level. Therefore, in the local group, there exists an inverted U-shape relationship between individual-level income inequality and subjective environmental pollution. According to the calculation, for about $95.4 \%$ of local people, their subjective environmental pollution decreases with the increase of individual income inequality.

Table 8. $t$ test of individual-level income inequality and subjective environmental pollution: differences between the locals and migrants.

\begin{tabular}{ccccccc}
\hline & \multicolumn{2}{c}{ Locals } & \multicolumn{2}{c}{ Migrants } & \multirow{2}{*}{ Diff. } & \multirow{2}{*}{$\boldsymbol{t}$} \\
\cline { 1 - 4 } & Mean & Obs. & Mean & Obs. & & \\
\hline inequality & 9.332 & 5241 & 9.047 & 2069 & $0.285^{* * *}$ & 15.453 \\
inequality $^{2}$ & 87.545 & 5241 & 82.462 & 2069 & $5.083^{* * *}$ & 15.601 \\
SEP & 2.827 & 5242 & 2.990 & 2069 & $-0.163^{* * *}$ & -4.793 \\
\hline
\end{tabular}

Note: Diff. denotes the differences of mean value between the locals and migrants. $t$ is $t$ statistics. Asterisks indicate the statistical significance, where ${ }^{* * *}$ is significant at a $1 \%$ level.

Table 9. The effect of individual-level income inequality on subjective environmental pollution: differences between the locals and migrants.

\begin{tabular}{|c|c|c|c|c|c|c|}
\hline & (1) & (2) & (3) & (4) & (5) & (6) \\
\hline & \multicolumn{3}{|c|}{ Local } & \multicolumn{3}{|c|}{ Migrant } \\
\hline inequality & $\begin{array}{c}2.127^{* * *} \\
(4.40)\end{array}$ & $\begin{array}{c}2.004^{* * *} \\
(3.80)\end{array}$ & $\begin{array}{c}1.407 * * \\
(2.49)\end{array}$ & $\begin{array}{c}1.312 * * \\
(2.05)\end{array}$ & $\begin{array}{l}0.943 \\
(1.44)\end{array}$ & $\begin{array}{l}0.393 \\
(0.63)\end{array}$ \\
\hline inequality $^{2}$ & $\begin{array}{c}-0.152 * * * \\
(-5.55)\end{array}$ & $\begin{array}{c}-0.124^{* * *} \\
(-4.12)\end{array}$ & $\begin{array}{c}-0.087^{* * *} \\
(-2.71)\end{array}$ & $\begin{array}{c}-0.094^{* *} \\
(-2.54)\end{array}$ & $\begin{array}{l}-0.048 \\
(-1.25)\end{array}$ & $\begin{array}{l}-0.015 \\
(-0.40)\end{array}$ \\
\hline Individual factors fixed effect & No & Yes & Yes & No & Yes & Yes \\
\hline Provincial factors fixed effect & No & No & Yes & No & No & Yes \\
\hline $\mathrm{N}$ & 5241 & 4885 & 4885 & 2069 & 1940 & 1940 \\
\hline
\end{tabular}

Notes: The parentheses show $t$ value of robust standard error. Asterisks indicate the statistical significance, where ${ }^{* *}$ and ${ }^{* * *}$ denote significance at the $5 \%$ and $1 \%$ levels, respectively. The results in this table are estimated by an ordered logit model. $\mathrm{N}$ is the number of observations.

Therefore, we can conclude that individual-level income inequality first increases and then decreases subjective environmental pollution for the locals. Meanwhile, the individuallevel income inequality of migrants has little impact on subjective environmental pollution when considering the effect of other factors.

\subsection{Difference in Gender}

We classified the samples into female and male groups according to their gender. Women significantly suffer from more income inequality than men, but there are no significant differences in subjective environmental pollution between males and females (see Table 10). The coefficients of linear inequality (inequality) and those of its square term $\left(\right.$ inequality ${ }^{2}$ ) are positive and negative at the $5 \%$ significance level, respectively (see Table 11), which means that an inverted U-shape curve exists between individual income inequality and subjective environmental pollution in the two groups. However, the coefficients of individual-level income inequality in the female group are larger. It means that females are more sensitive to the effect of individual income inequality on subjective environmental pollution. 
Table 10. $t$ test of individual-level income inequality and subjective environmental pollution: differences in gender.

\begin{tabular}{ccccccc}
\hline & \multicolumn{2}{c}{ The Female Group } & \multicolumn{2}{c}{ The Male Group } & \multirow{2}{*}{ Diff. } & \multirow{2}{*}{$\boldsymbol{t}$} \\
\cline { 1 - 4 } & Mean & Obs. & Mean & Obs. & & \\
\hline inequality & 9.438 & 3372 & 9.091 & 3942 & $0.347^{* * *}$ & 21.094 \\
inequality $^{2}$ & 89.483 & 3372 & 83.210 & 3942 & $6.273^{* * *}$ & 21.612 \\
SEP & 2.888 & 3372 & 2.860 & 3943 & 0.029 & 0.937 \\
\hline
\end{tabular}

Note: Diff. denotes the differences of mean value between the female group and male group, $t$ is $t$ statistics. Asterisks indicate the statistical significance, where ${ }^{* * *}$ denotes significance at the $1 \%$ level.

Table 11. The effect of individual-level income inequality on subjective environmental pollution: differences in gender.

\begin{tabular}{ccccccc}
\hline & $\mathbf{( 1 )}$ & $\mathbf{( 2 )}$ & $\mathbf{( 3 )}$ & $\mathbf{( 4 )}$ & (5) & The male group \\
\hline & \multicolumn{3}{c}{ The female group } \\
\hline inequality & $2.958^{* * *}$ & $2.700^{* * *}$ & $1.977^{* *}$ & $2.023^{* * *}$ & $1.763^{* * *}$ & $1.237^{* * *}$ \\
inequality & $(3.71)$ & $(3.02)$ & $(2.26)$ & $(4.48)$ & $(3.87)$ & $(2.59)$ \\
& $-0.195^{* * *}$ & $-0.155^{* * *}$ & $-0.111^{* *}$ & $-0.148^{* * *}$ & $-0.106^{* * *}$ & $-0.074^{* * *}$ \\
& $(-4.40)$ & $(-3.13)$ & $(-2.28)$ & $(-5.64)$ & $(-3.92)$ & $(-2.61)$ \\
\hline Individual factors fixed effect & No & Yes & Yes & No & Yes & Yes \\
Provincial factors fixed effect & No & No & Yes & No & No & 3704 \\
$N$ & 3372 & 3124 & 3124 & 3942 & 3704 \\
\hline
\end{tabular}

Notes: The parentheses show $t$ value of robust standard error. Asterisks indicate the statistical significance, where ${ }^{* *}$ and ${ }^{* * *}$ denote significance at $5 \%$ and $1 \%$ levels, respectively. About $84.1 \%$ of females think that individual-level income inequality decreases subjective environmental pollution, and about $86.3 \%$ of males think that individual-level income inequality decreases subjective environmental pollution. $\mathrm{N}$ is the number of observations.

Therefore, we conclude that individual-level income inequality has an inverted Ushape effect on subjective environmental pollution in the two groups. Females are more sensitive for the effect of individual-level income inequality on environmental pollution.

\subsection{Difference in Attention on Environmental Issues}

We divide the samples into the positive environmental attitude group and negative environmental attitude group according to whether the respondents put environmental issues as one of the first three most urgent problems to be solved (if the respondents put environmental issues as one of the first three most urgent problems that need to be solved, we think that they have a positive environmental attitude; otherwise, they are in the negative environmental attitude group). The respondents in the negative environmental attitude group have higher income inequality and better evaluation on environmental quality (see Table 12). The coefficients of inequality (inequality) and those of its square term (inequality ${ }^{2}$ ) are significantly negative and positive, respectively, in the two groups (see Table 13), which indicates that there exists an inverted U-shape relationship between individual income inequality and subjective environmental pollution. The coefficients of inequality (inequality) and those of its quadratic term (inequality ${ }^{2}$ ) in the positive environmental attitude group are larger, indicating that the subjective environmental pollution of the respondents in the positive environmental attitude group is more sensitive to the effect of individual-level income inequality. 
Table 12. $t$ test of individual-level income inequality and subjective environmental pollution: differences in environmental attitude.

\begin{tabular}{ccccccc}
\hline \multirow{2}{*}{ Variables } & \multicolumn{2}{c}{$\begin{array}{c}\text { Negative } \\
\text { Environmental Attitude }\end{array}$} & \multicolumn{2}{c}{$\begin{array}{c}\text { Positive Environmental } \\
\text { Pollution }\end{array}$} & \multirow{2}{*}{ Diff. } & $t$ \\
\cline { 1 - 4 } & Mean & Obs. & Mean & Obs. & & \\
\hline inequality & 9.292 & 6105 & 9.046 & 1209 & $0.246^{* * *}$ & 10.898 \\
inequality $^{2}$ & 86.826 & 6105 & 82.442 & 1209 & $4.384^{* * *}$ & 11.002 \\
SEP & 2.832 & 6106 & 3.080 & 1209 & $-0.248^{* * *}$ & -6.021 \\
\hline
\end{tabular}

Note: Diff. denotes the differences of mean value between the negative environmental attitude group and positive environmental attitude group, $t$ is $t$ statistics. Asterisks indicate the statistical significance, where ${ }^{* * *}$ denotes significance at $1 \%$ level.

Table 13. The effect of individual-level income inequality on subjective environmental pollution: differences in environmental attitude.

\begin{tabular}{ccccccc}
\hline & $\mathbf{( 1 )}$ & $\mathbf{( 2 )}$ & $\mathbf{( 3 )}$ & $\mathbf{( 4 )}$ & (5) \\
\hline & \multicolumn{3}{c}{ Negative attitude group } & \multicolumn{2}{c}{ Positive attitude group } \\
\hline inequality & $1.872^{* * *}$ & $1.588^{* * *}$ & $0.858^{*}$ & $2.312^{* * *}$ & $2.447^{* * *}$ & $2.143^{* * *}$ \\
inequality & $(3.90)$ & $(3.10)$ & $(1.67)$ & $(3.51)$ & $(3.62)$ & $(3.11)$ \\
& $-0.134^{* * *}$ & $-0.095^{* * *}$ & $-0.051^{*}$ & $-0.158^{* * *}$ & $-0.146^{* * *}$ & $-0.127^{* * *}$ \\
& $(-4.95)$ & $(-3.26)$ & $(-1.73)$ & $(-4.07)$ & $(-3.61)$ & $(-3.06)$ \\
\hline Individual factors fixed effect & No & Yes & Yes & No & Yes & Yes \\
Provincial factors fixed effect & No & No & Yes & No & No \\
$N$ & 6105 & 5696 & 5696 & 1209 & 1132 & 1132 \\
\hline
\end{tabular}

Notes: The parentheses show $t$ values of robust standard error. Asterisks indicate the statistical significance, where ${ }^{*}$ and ${ }^{* * *}$ denote significance at $10 \%$ and $1 \%$ levels, respectively. The results in this table are estimated by an ordered logit model. About $86.8 \%$ of individuals in the negative group think that individual-level income inequality decreases subjective environmental pollution, and $78.2 \%$ of respondents in the positive group have the same opinion. $\mathrm{N}$ is the number of observations.

In conclusion, individual-level income inequality has an inverted U-shape effect on subjective environmental pollution in the two groups, and the respondents in the positive group have a more sensitive reaction to individual-level income inequality.

\subsection{Mechanism}

\subsubsection{The Effect of Subjective Well-Being}

Using Equations (2)-(4), we estimate the role of subjective well-being in the effect of individual income inequality on subjective environmental pollution. The estimation results are shown in Table 14. The coefficients of inequality (inequality) and those of its square term $\left(\right.$ inequality $^{2}$ ) are significantly positive and negative, respectively (in columns 1,3, 4, and 6 in Table 14), which means that individual-level income inequality has an inverted U-shape effect on subjective environmental pollution. The coefficients of inequality to subjective well-being are negative (in columns 2 and 5 in Table 14), which indicates that income inequality decreases perceived well-being of individuals. The coefficients of subjective well-being to subjective environmental pollution are significantly negative at a $1 \%$ level (in columns 3 and 6 in Table 14), which means that an increase in subjective well-being decreases individual perceived subjective environmental pollution. 
Table 14. The mechanism of the effect of individual-level income inequality on subjective environmental pollution: the effect of subjective well-being.

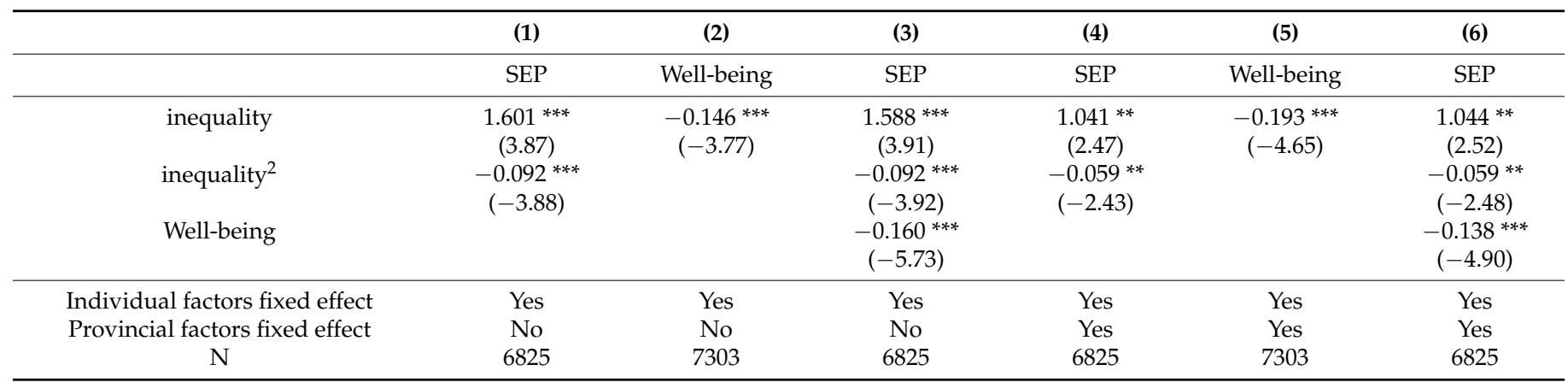

Notes: The parentheses show $t$ values of robust standard error. Asterisks indicate the statistical significance, where ${ }^{* *}$ and ${ }^{* * *}$ denote significance at $5 \%$ and $1 \%$ levels, respectively. The results in this table are estimated by ordered logit model. $\mathrm{N}$ is the number of observations.

Therefore, income inequality increases the subjective environmental pollution via subjective well-being. Income inequality decreases the individual subjective well-being, and a decrease in subjective well-being increases perceived environmental pollution.

\subsubsection{The Effect of Media Exposures}

Using Equation (5), we estimate the effect of media exposure on the nexus between individual income inequality and subjective environmental pollution. The results are reported in Table 15. Similar to the results in the previous section, the results in Table 15 support that an inverted U-shape relation exists between individual-level income inequality and subjective environmental pollution. The coefficients of the interactions of inequality and non-television media are significantly positive, which indicates that the effect of individual-level income inequality on subjective environmental pollution increases alongside an increase in non-television media exposure. Interestingly, the coefficient of the interaction of inequality and television media is negative but not significant, which supports the conclusion proposed by Lu and Sun (2018) [68] that television media has no significant impacts on environmental knowledge and environmental preference. The possible reasons are that modern television has limited abilities in the dissemination of environmental knowledge and environmental governance and that the environmental preference of the public is affected by various types of subjective information from government officials, experts, and environmental organizations through television.

Table 15. The mechanism of the effect of individual-level income inequality on subjective environmental pollution: the effect of media exposure.

\begin{tabular}{|c|c|c|c|c|c|c|}
\hline & (1) & (2) & (3) & (4) & (5) & (6) \\
\hline & newspaper & magazine & broadcasting & television & $\begin{array}{l}\text { Internet } \\
\text { (including } \\
\text { surfing the } \\
\text { Internet with } \\
\text { mobile phone) }\end{array}$ & $\begin{array}{l}\text { mobile } \\
\text { custom } \\
\text { message }\end{array}$ \\
\hline inequality & $\begin{array}{c}0.590 * * \\
(2.01)\end{array}$ & $\begin{array}{c}0.631 * * \\
(2.23)\end{array}$ & $\begin{array}{c}0.875^{* * *} \\
(2.97)\end{array}$ & $\begin{array}{c}0.900^{* * *} \\
(3.28)\end{array}$ & $\begin{array}{l}0.457 \\
(1.48)\end{array}$ & $\begin{array}{c}0.610 * * \\
(2.22)\end{array}$ \\
\hline inequality $^{2}$ & $\begin{array}{c}-0.039 * * \\
(-2.42)\end{array}$ & $\begin{array}{c}-0.043 * * * \\
(-2.73)\end{array}$ & $\begin{array}{c}-0.054^{* * *} \\
(-3.27)\end{array}$ & $\begin{array}{c}-0.052^{* * *} \\
(-3.31)\end{array}$ & $\begin{array}{c}-0.034^{* *} \\
(-2.03)\end{array}$ & $\begin{array}{c}-0.042^{* * *} \\
(-2.70)\end{array}$ \\
\hline media & $\begin{array}{l}-0.234 \\
(-1.48)\end{array}$ & $\begin{array}{c}-0.371 \text { ** } \\
(-2.15)\end{array}$ & $\begin{array}{l}-0.230 \\
(-1.42)\end{array}$ & $\begin{array}{l}0.004 \\
(0.02)\end{array}$ & $\begin{array}{c}-0.308^{* *} \\
(-2.33)\end{array}$ & $\begin{array}{c}-0.407^{* * *} \\
(-2.86)\end{array}$ \\
\hline Inequality $*$ media & $\begin{array}{c}0.029 * \\
(1.68)\end{array}$ & $\begin{array}{c}0.042^{* *} \\
(2.18)\end{array}$ & $\begin{array}{c}0.030 * \\
(1.68)\end{array}$ & $\begin{array}{l}-0.002 \\
(-0.09)\end{array}$ & $\begin{array}{c}0.036 * * \\
(2.50)\end{array}$ & $\begin{array}{c}0.049 * * * \\
(3.07)\end{array}$ \\
\hline Individual factor fixed effect & Yes & Yes & Yes & Yes & Yes & Yes \\
\hline Province factor fixed effect & Yes & Yes & Yes & Yes & Yes & Yes \\
\hline $\mathrm{N}$ & 6824 & 6822 & 6817 & 6819 & 6814 & 6818 \\
\hline $\mathrm{R}^{2}$ & 0.117 & 0.117 & 0.099 & 0.116 & 0.117 & 0.118 \\
\hline
\end{tabular}

Notes: The parentheses show $t$ values of robust standard error. Asterisks indicate the statistical significance, where * ${ }^{* *}$, and ${ }^{* *}$ denote significance at $10 \%, 5 \%$, and $1 \%$ levels, respectively. The results in this table are estimated by OLS. N is the number of observations. 
In conclusion, increasing the frequency of respondents' access to non-television media will amplify the effect of individual-level income inequality on subjective environmental pollution. Television media plays no role in the effect of income inequality on subjective environmental pollution.

\section{Conclusions}

This paper uses CGSS2013 data and an ordered logit model to analyze the relationship between individual-level income inequality and subjective environmental pollution. The results show that individual-level income inequality has an inverted U-shape effect on subjective environmental pollution; that is, the increase of an individual's income inequality will first increase then decrease the respondents' feeling of environmental pollution after reaching the peak. The subjective environmental pollution increases following the decrease of income inequality for approximately $84 \%$ of respondents in China. The robustness test supports these conclusions.

Further classifying the samples according to the characteristics of respondents, we find existing different effects of individual-level income inequality on subjective environmental pollution among different groups. Income inequality has an obviously inverted U-shape effect on subjective environmental pollution for the urban residents and the locals, but we cannot get an inverted U-shape curve relation between income inequality and subjective environmental pollution for the rural residents and the migrants. An inverted U-shape curve exists between individual-level income inequality and subjective environmental pollution under the classifications of gender and environmental attitude. However, for females and the respondents who have positive environmental attitudes, the subjective environmental pollution is more sensitive to the effect of income inequality. We also find that subjective well-being plays a mediating role in the effect of income inequality on subjective environmental pollution. Income inequality increases the perceived subjective environmental pollution via subjective well-being. The results show that exposing to nontelevision media plays a moderation role in the effect of income inequality on subjective environmental pollution, but the moderation effect of television media is not significant. The effect of income inequality on subjective environmental pollution increases as nontelevision media exposure rises.

These findings enhanced our understanding of the relationship and potential mechanism between individual income inequality and subjective environmental pollution. It can be seen that individual income inequality has an inverted U-shape effect on subjective environmental pollution. We strongly recommend that the government implement prudent income redistribution policies to improve individuals' subjective environmental quality. Narrowing the income gap among individuals does not always improve their subjective evaluation on environmental quality. When an individual-level income gap is larger, income redistribution from the rich to the poor will increase the subjective evaluation of environmental pollution of the overall residents. When the income gap among individuals is smaller, narrowing the income gap among individuals will decrease the subjective environmental pollution of residents. Hence, when individual income inequality is low, income distribution from rich to poor may decrease subjective environmental pollution; when individual income inequality is high, the income distribution policy implemented by the government plays no roles in improving individuals' subjective environmental quality. Additionally, subjective environmental pollution is mainly decided by objective environmental pollution. The government should positively improve objective (actual) environmental pollution to decrease the residents' subjective environmental pollution.

There still exist some limitations in the paper. First, due to the limitation of data, this paper only controls air pollution, water pollution, and garbage pollution at the province level; meanwhile, there may exist other pollutions that impact subjective environmental pollution, such as waste pollution and so on. Hence, it is very necessary to use more micro data, such as city-level or county-level data, and more kinds of pollutants, to control the effect of objective environmental pollution in the future. Second, for protecting the 
privacy of the respondents, the CGSS team only releases the residential addresses of the respondents at the province level, so we cannot merge more detailed information at the street, county, or city level. The control variables at the province level may be too rough to control more factors that the respondents face. Based on that, using more micro and detailed information of each individual is another future direction. Third, we do not explain and verify the reason why an inverse U-shape relationship exists between individual-level income inequality and subjective environmental pollution, because of the lack of the habitations of the respondents. We infer the possible explanation that the poorer who suffer from more income inequality live in undeveloped areas with good environmental quality and the richer who have relatively less income inequality can freely choose the area with good environmental quality to live in; hence, they both have higher evaluations on environmental quality. Hence, future studies could use more detailed data to explain and verify the reason why individual income inequality affect subjective environmental pollution.

Author Contributions: Conceptualization, B.L.; Data curation, B.L.; Formal analysis, B.L.; Funding acquisition, D.X.; Methodology, B.L.; Resources, D.X.; Supervision, D.X.; Writing—original draft, B.L. and D.X.; Writing-review and editing, B.L. All authors have read and agreed to the published version of the manuscript.

Funding: This paper was supported by the Key Program of the National Social Science Fund (grant number: 19AJL016; grant number: 19AJL004), the General Program of the National Social Science Fund (grand number: 20BJL140) and the National Natural Science Foundation Youth Project (grant number: 71904045).

Institutional Review Board Statement: The data released by the project team of the China General Social Survey (CGSS) have deleted the respondents' privacy information. The applicants can directly apply for the data online to obtain the data without ethical review of the data.

Informed Consent Statement: The project team of the CGSS conducts the survey only after obtaining the informed consent of all respondents. The applicants can directly obtain and use the public data.

Data Availability Statement: The data presented in this study are available through the website of CGSS (cnsda.ruc.edu.cn) (accessed on 30 September 2019).

Conflicts of Interest: The authors declare no conflict of interest. 


\section{Appendix A}

Table A1. Person correlation coefficient test.

\begin{tabular}{|c|c|c|c|c|c|c|c|c|c|c|c|c|c|c|c|c|c|c|c|c|c|}
\hline & SEP & Inequality & Inequality ${ }^{2}$ & $\begin{array}{c}\text { Env } \\
\text { Behavior }\end{array}$ & $\begin{array}{c}\text { Env } \\
\text { Know }\end{array}$ & Gender & 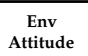 & Ind Cong & Health & $\begin{array}{l}\text { Well- } \\
\text { Being }\end{array}$ & Migrant & Lnphi & $\operatorname{lnPGDP}$ & lnPGDP2 & Pop Den & pm25 & Garbarge & Nox & so2 & Wat Poll & Smoke \\
\hline $\begin{array}{c}\text { SEP } \\
\text { inequality } \\
\text { inequality }\end{array}$ & $\begin{array}{c}1.000 \\
-0.209 * * \\
-0.214^{* *}\end{array}$ & $\begin{array}{l}1.0000 \\
0.997 * * *\end{array}$ & 1.000 & & & & & & & & & & & & & & & & & & \\
\hline $\begin{array}{l}\text { env } \\
\text { behavior }\end{array}$ & $0.122 * *$ & -0.117 ** & $-0.117 *$ & 1.000 & & & & & & & & & & & & & & & & & \\
\hline $\begin{array}{l}\text { behavior } \\
\text { env know } \\
\text { gender }\end{array}$ & $\begin{array}{l}0.212 * * * \\
-0.009\end{array}$ & $\begin{array}{l}-0.311^{* *} \\
-0.239^{* *}\end{array}$ & $\begin{array}{l}-0.314 \text { ** } \\
-0.245 \text { ** }\end{array}$ & $\begin{array}{l}0.085 \text { ** * } \\
0.025 *\end{array}$ & $\begin{array}{l}1.000 \\
0.093 * *\end{array}$ & 1.000 & & & & & & & & & & & & & & & \\
\hline env & 0.083 ** & -0.116 ** & -0.117 ** & 0.040 ** & $0.109 *$ & -0.021 & 1.000 & & & & & & & & & & & & & & \\
\hline 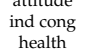 & $\begin{array}{l}0.225 * * \\
0.267^{* *}\end{array}$ & $\begin{array}{l}-0.366^{* *} \\
-0.178 *\end{array}$ & $\begin{array}{l}-0.365 \text { ** } \\
-0.182^{* *}\end{array}$ & $\begin{array}{l}0.109 * * * \\
0.042 * *\end{array}$ & $\begin{array}{l}0.422 * * \\
0.168 * *\end{array}$ & $\begin{array}{l}-0.025 * \\
0.035 \text { * }\end{array}$ & $\begin{array}{l}0.100^{* *} \\
0.057 * *\end{array}$ & $\begin{array}{c}1.000 \\
0.281^{* *}\end{array}$ & 1.000 & & & & & & & & & & & & \\
\hline well- & $-0.048 * *$ & -0.082 ** & $-0.082 * *$ & -0.034 & $0.046 *$ & -0.046 ** & $0.054 * *$ & 0.075 ** & 0.212 **t & 1.000 & & & & & & & & & & & \\
\hline $\begin{array}{l}\text { being } \\
\text { migrant }\end{array}$ & 0.081 ** & -0.178 ** & $-0.180 * *$ & -0.001 & $0.102 * *$ & $-0.065^{\text {** }}$ & 0.013 & $0.138^{* *}$ & 0.002 & $0.037^{\text {*t }}$ & 1.000 & & & & & & & & & & \\
\hline 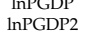 & $\begin{array}{l}0.260 \text { **t } \\
0.26\end{array}$ & $\begin{array}{l}-0.0636 \\
-0.367^{* *}\end{array}$ & 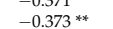 & $\begin{array}{l}0.0866 \\
0.087 * *\end{array}$ & 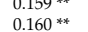 & $\begin{array}{l}-0.0 .099 \\
-0.008\end{array}$ & $\begin{array}{l}0.0991 * * \\
0.092 * *\end{array}$ & $\begin{array}{l}0.2800 * \\
0.281 * *\end{array}$ & & $\begin{array}{l}0.016 \\
0.016\end{array}$ & $0.146^{* *}$ & $\begin{array}{l}0.4444^{* *} \\
0.447^{*}\end{array}$ & $\begin{array}{r}1.000 \\
1.000 * *\end{array}$ & 100 & & & & & & & \\
\hline pop den & $-0.044 * *$ & $0.099 * *$ & 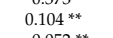 & 0.021 & -0.018 & $\begin{array}{l}-.0008 \\
0.008\end{array}$ & $-0.059 * *$ & - & $\begin{array}{l}0.0915 \text { * } \\
-0.075 *\end{array}$ & $\begin{array}{l}-0.016 \\
-0.046 *\end{array}$ & $-0.072 * *$ & -0.108 ** & -0.346 ** & $\begin{array}{l}1.0 .000 \\
-0.344^{* *}\end{array}$ & 1.000 & & & & & & \\
\hline pm25 & $0.103^{* * *}$ & $-0.052 * *$ & -0.052 *** & $0.026 *$ & $0.024 *$ & -0.038 *** & $0.063^{* * *}$ & 0.021 & $0.068^{* * *}$ & -0.030 ** & $-0.058 * *$ & $0.096 * *$ & $0.333^{* *}$ & $0.335^{* * *}$ & $-0.168 * *$ & 1.000 & & & & & \\
\hline garbage & $\begin{array}{c}0.022 \\
0.0120 *\end{array}$ & $\begin{array}{l}-0.112 * * \\
x^{* 18 *}\end{array}$ & 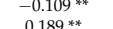 & $\begin{array}{l}0.024 * \\
-0.055^{* * *}\end{array}$ & $\begin{array}{l}0.073 * * \\
-0.009\end{array}$ & $\begin{array}{l}-0.011 \\
0^{* 0.05 * *}\end{array}$ & $\begin{array}{l}0.005 \\
-0.19\end{array}$ & 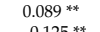 & $\begin{array}{l}0.063^{* * *} \\
0.059 * *\end{array}$ & 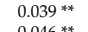 & $0.050 * *$ & $0.123^{* *}$ & $0.317 * *$ & $0.309 * *$ & -0.165 ** & $0.178^{* *}$ & 1.000 & & & & \\
\hline $\begin{array}{l}\text { nox } \\
\text { so2 }\end{array}$ & $\begin{array}{l}-0.1201 * * \\
-0.161 *\end{array}$ & $\begin{array}{l}0.1862 * * \\
0.182 *\end{array}$ & $0.268 * *$ & $\begin{array}{l}-0.060 \\
-0.081\end{array}$ & $\begin{array}{l}-0.0009 * \\
-0.052^{* *}\end{array}$ & $\begin{array}{l}-0.0535 * \\
-0.027 *\end{array}$ & $\begin{array}{l}-0.019 \\
-0.028^{*}\end{array}$ & $\begin{array}{l}-0.125 * * \\
-0.213 *\end{array}$ & $\begin{array}{l}0.0599^{* * *} \\
0.03 \% * *\end{array}$ & $\begin{array}{l}0.0 .066^{* * * *} \\
0.042 * *\end{array}$ & $\begin{array}{l}-0.102{ }^{2 *} \\
-0.14 *\end{array}$ & $\begin{array}{l}-0.1811^{* *} \\
-0.78 *\end{array}$ & $\begin{array}{l}-0.245 * * \\
-0.47 * *\end{array}$ & $\begin{array}{l}-0.254 * * \\
-048 * *\end{array}$ & $\begin{array}{l}-0.003 \\
-0.04\end{array}$ & $\begin{array}{l}0.1999 * * \\
0.077 * *\end{array}$ & $\begin{array}{l}0.508 * * * \\
0.316 * *\end{array}$ & $\begin{array}{l}1.000 \\
0.9007 * *\end{array}$ & 1000 & & \\
\hline $\begin{array}{l}\text { soz } \\
\text { wat poll } \\
\text { smoke }\end{array}$ & 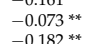 & $\begin{array}{l}0.202 \\
-0.015 \\
-0.099 * *\end{array}$ & $\begin{array}{l}-.2001 \\
-0.011 \\
0301 * *\end{array}$ & 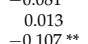 & $\begin{array}{l}-0.022 \\
0.010 \\
-0.076 * * *\end{array}$ & $\begin{array}{l}-0.027 \\
-0.018 \\
-0.026 *\end{array}$ & $\begin{array}{c}-0.028 \\
0.012 \\
-0.059 * *\end{array}$ & $\begin{array}{l}-0.213 \\
-0.018 \\
-0.175 * *\end{array}$ & $\begin{array}{l}0.0057 * * * \\
0.057 * *\end{array}$ & $\begin{array}{l}0.0 .024 * \\
0.029 *\end{array}$ & $\begin{array}{l}-0.114 * \\
-0.026 *\end{array}$ & $\begin{array}{c}-0.270 \\
0.010 \\
-0323 * *\end{array}$ & $\begin{array}{c}-0.470 \\
0.125 * * \\
-0519^{* * *}\end{array}$ & $\begin{array}{l}-0.404 * \\
0.117 \\
-0.52 * * *\end{array}$ & $\begin{array}{l}-0.1904 * * \\
-0.190 *\end{array}$ & $\begin{array}{l}0.345 * * \\
0.34177^{* * *}\end{array}$ & 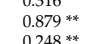 & 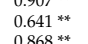 & $\begin{array}{l}1.000 \\
0.485 * * \\
0.878 * * *\end{array}$ & $\begin{array}{l}1.000 \\
0.599^{* * *}\end{array}$ & 100 \\
\hline
\end{tabular}


Table A2. Akaike's and Schwarz's Bayesian information criteria.

\begin{tabular}{ccccccc}
\hline \multirow{2}{*}{ Model } & \multicolumn{2}{c}{ Model 1 } & \multicolumn{2}{c}{ Model 2 } & \multicolumn{2}{c}{ Model 3 } \\
\cline { 2 - 7 } & AIC & BIC & AIC & BIC & AIC & BIC \\
\hline OLS & $24,261.9$ & $24,282.59$ & $22,229.68$ & $22,311.62$ & $21,916.78$ & $22,060.18$ \\
OLM & $46,060.09$ & $46,246.32$ & $42,537.73$ & $42,783.55$ & $42,219.33$ & $42,526.6$ \\
\hline
\end{tabular}

Note: Model 1 denotes the model that only includes individual income inequality and its square. Model 2 is the model that controls individual characteristics based on Model 1. Model 3 further controls the effect of city factors based on Model 2.

Table A3. Ramsey RESET test.

\begin{tabular}{cccc}
\hline Model & Model 1 & Model 2 & Model 3 \\
\hline F & 22.44 & 5.23 & 4.84 \\
$p$-value & 0.0000 & 0.0013 & 0.0023 \\
\hline
\end{tabular}

Note: Model 1 denotes the model that only includes individual income inequality and its square. Model 2 is the model that controls individual characteristics based on Model 1. Model 3 further controls the effect of city factors based on Model 2.

Table A4. Mean of individual-level income inequality and subjective environmental pollution for the respondents that use different media and have different use frequency.

\begin{tabular}{ccccccc}
\hline Variables & Frequency & Never & Rarely & Sometimes & Often & Very Often \\
\hline \multirow{2}{*}{ newspaper } & RD & 9.56 & 9.22 & 9.07 & 8.93 & 8.75 \\
& SEP & 2.58 & 2.93 & 3.16 & 3.14 & 2.95 \\
magazine & RD & 9.48 & 9.15 & 9.02 & 8.94 & 8.67 \\
broadcasting & SEP & 2.68 & 2.99 & 3.11 & 3.04 & 2.9 \\
television & RD & 9.38 & 9.19 & 9.09 & 9.1 & 8.94 \\
internet(including & SEP & 2.71 & 2.95 & 3.11 & 3.16 & 2.92 \\
mobile phone & RD & 9.33 & 9.18 & 9.2 & 9.26 & 9.26 \\
mobile custom & SEP & 2.81 & 2.92 & 2.91 & 2.91 & 2.82 \\
message & RD & 9.52 & 9.17 & 9.08 & 8.97 & 8.8 \\
\hline
\end{tabular}

Table A5. Variable description.

\begin{tabular}{|c|c|}
\hline Variables & Description \\
\hline Air pollution & $\begin{array}{l}\text { Subjective air pollution: } 0=\text { this problem does not exist, } 1=\text { indifferent, } 2=\text { not serious, } 3=\text { very } \\
\text { serious, } 4=\text { somewhat serious, and } 5=\text { very serious }\end{array}$ \\
\hline Water pollution & $\begin{array}{c}\text { Subjective water pollution: } 0=\text { this problem does not exist, } 1=\text { indifferent, } 2=\text { not serious, } 3=\text { very } \\
\text { serious, } 4=\text { somewhat serious, and } 5=\text { very serious }\end{array}$ \\
\hline Noise pollution & $\begin{array}{c}\text { Subjective noise pollution: } 0=\text { this problem does not exist, } 1=\text { indifferent, } 2=\text { not serious, } 3=\text { very } \\
\text { serious, } 4=\text { somewhat serious, and } 5=\text { very serious }\end{array}$ \\
\hline Industrial waste pollution & $\begin{array}{l}\text { Subjective industrial waste pollution: } 0=\text { this problem does not exist, } 1=\text { indifferent, } 2=\text { not serious, } \\
\qquad 3=\text { very serious, } 4=\text { somewhat serious, and } 5=\text { very serious }\end{array}$ \\
\hline Garbage pollution & $\begin{array}{c}\text { Subjective garbage pollution: } 0=\text { this problem does not exist, } 1=\text { indifferent, } 2=\text { not serious, } 3=\text { very } \\
\text { serious, } 4=\text { somewhat serious, and } 5=\text { very serious }\end{array}$ \\
\hline S & Subjective environmental pollution \\
\hline Yitzhaki ${i n_{i} r_{a}}_{1}$ & Yitzhaki index, which is calculated by the personal income of respondents in full samples \\
\hline Yitzhaki ${i n_{i} r_{s}}$ & Yitzhaki index, which is calculated by the personal income of respondents that have non-z \\
\hline Yitzhaki $i_{i n_{h} r_{s}}$ & $\begin{array}{c}\text { Yitzhaki index, which is calculated by the total household income of respondents that have non-zero } \\
\text { income }\end{array}$ \\
\hline Yitzhaki $i_{i n_{p} r_{s}}$ & $\begin{array}{l}\text { Yitzhaki index, which is calculated by the household income per capita of respondents that have } \\
\text { non-zero income }\end{array}$ \\
\hline Kakwani $_{\text {in }_{i} r_{a}}$ & Kakwani index, which is calculated by the personal income of respondents in full samples \\
\hline Kakwani $_{\text {in }_{i} r_{s}}$ & $\begin{array}{c}\text { Kakwani index, which is calculated by the personal income of respondents that have non-zero } \\
\text { income }\end{array}$ \\
\hline Kakwani $_{\text {in }_{h} r_{s}}$ & $\begin{array}{c}\text { Kakwani index, which is calculated by the total household income of respondents that have non-zero } \\
\text { income }\end{array}$ \\
\hline
\end{tabular}


Table A5. Cont.

\begin{tabular}{|c|c|}
\hline Variables & Description \\
\hline Kakwani $_{i n_{p} r_{s}}$ & $\begin{array}{l}\text { Kakwani index, which is calculated by the household income per capita of respondents that have } \\
\text { non-zero income }\end{array}$ \\
\hline env behavior & the behavior of environment \\
\hline env know & the knowledge of environment \\
\hline gender & male $=1$ and female $=0$ \\
\hline env attitude & environmental attitude \\
\hline ind $\operatorname{cog}$ & cognitive level \\
\hline health & 1-very unhealthy; 2-relatively unhealthy; 3-general; 4 -relatively healthy; 5-very healthy \\
\hline well-being & $\begin{array}{c}\text { 1-very unhappy; 2-less happy; 3-cannot say happiness or unhappiness; } 4 \text {-comparatively happy; } \\
\text { 5-very happy }\end{array}$ \\
\hline migrant & migrant $=1$ and the local $=0$ \\
\hline lnphi & the logarithm of household income per capita \\
\hline $\ln P G D P$ & the logarithm of GDP per capita \\
\hline $\ln P G D P 2$ & the square of $\ln P G D P$ \\
\hline pop den & the logarithm population density \\
\hline $\mathrm{pm}_{2.5}$ & the logarithm of the concentration of $\mathrm{PM}_{2.5}$ \\
\hline garbage & the logarithm of the amount of municipal solid waste \\
\hline nox & the logarithm of total emission of NOx \\
\hline so2 & the logarithm of total emission of $\mathrm{SO}_{2}$ \\
\hline wat poll & the logarithm of total discharge of waste water \\
\hline smo & the logarithm of total emission of smoke (dust) \\
\hline
\end{tabular}

Table A6. The effect of individual-level income inequality on different subjective environmental pollution.

\begin{tabular}{|c|c|c|c|c|c|}
\hline & (1) & (2) & (3) & (4) & (5) \\
\hline \multirow{3}{*}{ inequality } & Air pollution & Water pollution & Noise pollution & Industrial waste pollution & Garbage pollution \\
\hline & $1.252^{* * *}$ & $0.945^{* *}$ & $1.973^{* * *}$ & $0.752 *$ & $0.819 *$ \\
\hline & $(2.79)$ & $(2.32)$ & $(4.77)$ & $(1.71)$ & $(1.90)$ \\
\hline \multirow[t]{2}{*}{ inequality $^{2}$} & $-0.074^{* * *}$ & $-0.056^{* *}$ & $-0.118^{* * *}$ & $-0.044^{*}$ & $-0.043^{*}$ \\
\hline & $(-2.86)$ & $(-2.40)$ & $(-4.95)$ & $(-1.75)$ & $(-1.72)$ \\
\hline \multirow[t]{2}{*}{ lnphi } & $0.170^{* * *}$ & $0.072^{* *}$ & $0.155^{* * *}$ & $0.108^{* * *}$ & $0.127^{* * *}$ \\
\hline & $(4.85)$ & $(2.08)$ & $(4.41)$ & (3.09) & $(3.63)$ \\
\hline \multirow{2}{*}{ env behavior } & $0.282 * * *$ & $0.381^{* * *}$ & $0.286^{* * *}$ & $0.385^{* * *}$ & $0.266^{* * *}$ \\
\hline & $(4.24)$ & $(5.68)$ & $(4.30)$ & $(5.92)$ & (4.19) \\
\hline \multirow[t]{2}{*}{ env know } & $0.057^{* * *}$ & $0.069^{* * *}$ & $0.066^{* * *}$ & $0.052^{* * *}$ & $0.051^{* * *}$ \\
\hline & (6.11) & (7.32) & $(6.98)$ & $(5.54)$ & (5.37) \\
\hline \multirow[t]{2}{*}{ gender } & $-0.077^{*}$ & $-0.082 *$ & $-0.114^{* *}$ & -0.030 & -0.030 \\
\hline & $(-1.65)$ & $(-1.74)$ & $(-2.43)$ & $(-0.63)$ & $(-0.64)$ \\
\hline \multirow[t]{2}{*}{ env attitude } & $0.142^{* * *}$ & $0.107^{* * *}$ & $0.055^{*}$ & 0.040 & 0.020 \\
\hline & $(4.65)$ & $(3.44)$ & $(1.86)$ & $(1.29)$ & $(0.67)$ \\
\hline \multirow[t]{2}{*}{ ind cong } & $0.232^{* * *}$ & $0.138^{* * *}$ & $0.224^{* * *}$ & $0.192^{* * *}$ & $0.204^{* * *}$ \\
\hline & (6.28) & (3.70) & (6.13) & (5.11) & (5.58) \\
\hline \multirow[t]{2}{*}{ health } & $-0.053^{* *}$ & -0.014 & -0.031 & $0.051 * *$ & 0.012 \\
\hline & $(-2.32)$ & $(-0.60)$ & $(-1.32)$ & $(2.18)$ & $(0.51)$ \\
\hline \multirow[t]{2}{*}{ well-being } & $-0.122^{* * *}$ & $-0.121^{* * *}$ & $-0.133^{* * *}$ & $-0.171^{* * *}$ & $-0.126^{* * *}$ \\
\hline & $(-4.10)$ & $(-4.17)$ & $(-4.45)$ & $(-5.84)$ & $(-4.37)$ \\
\hline \multirow[t]{2}{*}{$\operatorname{lnPGDP}$} & $-18.857^{* * *}$ & -1.048 & 3.388 & 3.335 & 1.970 \\
\hline & $(-4.32)$ & $(-0.25)$ & $(0.77)$ & $(0.92)$ & $(0.52)$ \\
\hline \multirow[t]{2}{*}{$\operatorname{lnPGDP2}$} & $0.914^{* * *}$ & 0.053 & -0.124 & -0.121 & -0.076 \\
\hline & $(4.50)$ & $(0.27)$ & $(-0.61)$ & $(-0.73)$ & $(-0.43)$ \\
\hline \multirow[t]{2}{*}{ pop den } & 0.058 & -0.095 & $0.156^{* *}$ & $0.268^{* * *}$ & 0.111 * \\
\hline & $(0.95)$ & $(-1.53)$ & $(2.46)$ & (4.34) & $(1.83)$ \\
\hline \multirow[t]{2}{*}{ pm25 } & $0.587^{* * *}$ & $0.427^{* * *}$ & $0.274^{* * *}$ & $0.319^{* * *}$ & -0.040 \\
\hline & $(8.90)$ & (6.33) & (3.99) & $(5.60)$ & $(-0.70)$ \\
\hline \multirow[t]{2}{*}{ garbage } & $0.562^{* * *}$ & $0.701^{* * *}$ & $0.921^{* * *}$ & -0.072 & $-0.271^{* * *}$ \\
\hline & (5.82) & (7.41) & $(9.52)$ & $(-1.45)$ & $(-5.34)$ \\
\hline \multirow[t]{2}{*}{ nox } & $-0.374^{* *}$ & -0.036 & $-0.525^{* * *}$ & $-0.557^{* * *}$ & -0.009 \\
\hline & $(-2.26)$ & $(-0.21)$ & $(-3.00)$ & $(-4.70)$ & $(-0.08)$ \\
\hline \multirow[t]{2}{*}{ so2 } & $0.214^{* *}$ & $0.185^{*}$ & $0.633^{* * *}$ & $0.422^{* * *}$ & 0.074 \\
\hline & $(2.14)$ & $(1.81)$ & $(6.30)$ & $(4.20)$ & $(0.77)$ \\
\hline \multirow[t]{2}{*}{ wat poll } & $-0.679 * * *$ & $-0.665^{* * *}$ & $-1.086^{* * *}$ & & \\
\hline & $(-7.00)$ & $(-6.87)$ & $(-10.98)$ & & \\
\hline \multirow[t]{2}{*}{ smoke } & $0.224 *$ & $-0.201 *$ & -0.019 & & \\
\hline & $(1.88)$ & $(-1.74)$ & $(-0.16)$ & & \\
\hline $\mathrm{N}$ & 6825 & 6825 & 6825 & 6825 & 6825 \\
\hline
\end{tabular}

Notes: The parentheses show $t$ values of robust standard error. Asterisks indicate the statistical significance, where ${ }^{*}, * *$, and ${ }^{* * *}$ denote significance at $10 \%, 5 \%$, and $1 \%$ levels, respectively. The results are estimated by an ordered logit model. 
Table A7. The effect of individual-level income inequality on subjective environmental pollution: robustness test based on different measurements of income inequality at the individual level.

\begin{tabular}{|c|c|c|c|c|c|c|c|}
\hline & (1) & (2) & (3) & (4) & (5) & (6) & (7) \\
\hline & Yitzhaki $_{i{ }_{i} r_{S}}$ & Yitzhaki $_{i n_{h} r_{S}}$ & Yitzhaki $_{\text {inpr }}$ & Kakwani $_{i n_{i} r_{a}}$ & Kakwani $_{i n_{i} r_{s}}$ & Kakwani $_{\text {in }_{h i} r_{S}}$ & Kakwani $_{\text {inp }} r_{s}$ \\
\hline inequality & $\begin{array}{c}1.784 * * * \\
(3.84)\end{array}$ & $\begin{array}{c}1.835 * * \\
(2.08)\end{array}$ & $\begin{array}{c}6.231^{* * * *} \\
(4.38)\end{array}$ & $\begin{array}{l}0.435 \\
(1.13)\end{array}$ & $\begin{array}{c}1.400 * * * \\
(3.35)\end{array}$ & $\begin{array}{c}1.119 * * * \\
(2.59)\end{array}$ & $\begin{array}{l}0.121 \\
(0.21)\end{array}$ \\
\hline inequality $^{2}$ & $\begin{array}{c}-0.103 * * * * \\
(-3.84)\end{array}$ & -0.086 * & $\begin{array}{c}-0.362 * * * \\
(-4.27)\end{array}$ & $\begin{array}{l}-0.597 * \\
(-1.91)\end{array}$ & $\begin{array}{l}-1.780 * * * * \\
(-4.75)\end{array}$ & $\begin{array}{l}-0.910 * * \\
(-2.34)\end{array}$ & -1.601 *** \\
\hline lnphi & $\begin{array}{l}0.203^{* * * *} \\
(5.28)\end{array}$ & $\begin{array}{l}0.252^{* * *} \\
(5.41)\end{array}$ & 0.047 & $0.150^{* * *}$ & $0.155^{* * *}$ & $0.218^{* * *}$ & $-0.166^{*}$ \\
\hline env behavior & $\begin{array}{c}(5.28) \\
0.433^{* * *} \\
(6.14)\end{array}$ & $\begin{array}{c}(5.41) \\
0.457 * * * \\
(6.72)\end{array}$ & $\begin{array}{c}(0.55)^{* * *} \\
(6.65)\end{array}$ & $\begin{array}{c}(4.43) \\
0.452 * * * \\
(6.63)\end{array}$ & $\begin{array}{c}(4.03) \\
0.440 * * * \\
(6.28)\end{array}$ & $\begin{array}{c}(4.55) \\
0.459 * * * \\
(6.74)\end{array}$ & $\begin{array}{l}(-1.77) \\
0.454^{* * *} \\
(6.67)\end{array}$ \\
\hline env know & $\begin{array}{l}0.067^{* * * *} \\
(6.84)\end{array}$ & $0.071^{* * *}$ & $0.069 * * *$ & $\begin{array}{l}0.070^{* * *} \\
(7.54)\end{array}$ & $0.067^{* * *}$ & $0.072^{* * *}$ & $0.069^{* * *}$ \\
\hline gender & $\begin{array}{l}-0.047 \\
(-0.96)\end{array}$ & -0.052 & -0.051 & $-0.087 *$ & -0.056 & $\begin{array}{l}-0.052 \\
-120\end{array}$ & $\begin{array}{c}(7.42) \\
-0.050 \\
(-1.16)\end{array}$ \\
\hline env attitude & $\begin{array}{c}0.082^{* * *} \\
(2.77)\end{array}$ & $\begin{array}{c}0.090^{* * *} \\
(3.18)\end{array}$ & $\begin{array}{c}0.090^{* * * *} \\
(3.21)\end{array}$ & $\begin{array}{c}0.087^{* * * *} \\
(3.07)\end{array}$ & $\begin{array}{c}0.082^{* * *} \\
(2.76)\end{array}$ & $\begin{array}{c}0.088^{* * * *} \\
(3.12)\end{array}$ & $\begin{array}{c}0.091^{* * *} \\
(3.23)\end{array}$ \\
\hline ind cong & $\begin{array}{c}0.203 * * * \\
(5.13)\end{array}$ & $\begin{array}{c}0.232 * * * \\
(6.26)\end{array}$ & $\begin{array}{c}0.234 * * * \\
(6.27)\end{array}$ & $\begin{array}{c}0.223 * * * \\
(5.97)\end{array}$ & $\begin{array}{l}0.202 * * * \\
(5.10)\end{array}$ & $\begin{array}{c}0.228^{* * * *} \\
(6.17)\end{array}$ & $\begin{array}{c}0.232^{* * * *} \\
(6.24)\end{array}$ \\
\hline health & $\begin{array}{l}-0.007 \\
(-0.31)\end{array}$ & $\begin{array}{l}-0.003 \\
(-0.14)\end{array}$ & $\begin{array}{l}-0.006 \\
(-0.25)\end{array}$ & $\begin{array}{l}-0.007 \\
(-0.29)\end{array}$ & $\begin{array}{l}-0.018 \\
(-0.75)\end{array}$ & $\begin{array}{l}-0.004 \\
(-0.16)\end{array}$ & $\begin{array}{l}-0.006 \\
(-0.25)\end{array}$ \\
\hline well-being & $\begin{array}{c}-0.178 * * * \\
(-5.93)\end{array}$ & $\begin{array}{l}-0.162^{* * * *} \\
(-5.63)\end{array}$ & $\begin{array}{c}-0.167 * * * \\
(-5.83)\end{array}$ & $\begin{array}{c}-0.165 * * * * \\
(-5.75)\end{array}$ & $\begin{array}{c}-0.174 * * * * \\
(-5.80)\end{array}$ & $\begin{array}{c}-0.163 * * * * \\
(-5.66)\end{array}$ & $\begin{array}{c}-0.166 * * * * \\
(-5.81)\end{array}$ \\
\hline $\operatorname{lnPGDP}$ & $\begin{array}{l}-4.421 \\
-100\end{array}$ & $\begin{array}{l}-6.640 \\
(-156)\end{array}$ & $\begin{array}{l}-5.724 \\
-(34)\end{array}$ & $\begin{array}{l}-6.435 \\
(-151\end{array}$ & $\begin{array}{l}-4.540 \\
-(102)\end{array}$ & $-7.163^{*}$ & $\begin{array}{r}-5.766 \\
(-136\end{array}$ \\
\hline InPGDP2 & $\begin{array}{c}(-1.00) \\
0.228 \\
(1.10)\end{array}$ & $\begin{array}{l}(-1.56) \\
0.334^{*} \\
(1.69)\end{array}$ & $\begin{array}{c}(-1.34) \\
0.291 \\
(1.47)\end{array}$ & $\begin{array}{c}(-1.51) \\
0.325 \\
(1.64)\end{array}$ & $\begin{array}{l}(-1.02) \\
0.233 \\
(1.12)\end{array}$ & $\begin{array}{c}(-1.68) \\
0.359^{*} \\
(1.81)\end{array}$ & $\begin{array}{c}(-1.36) \\
0.293 \\
(1.48)\end{array}$ \\
\hline pop den & $\begin{array}{l}0.014 \\
(0.22)\end{array}$ & $\begin{array}{l}0.041 \\
(0.67)\end{array}$ & $\begin{array}{l}0.056 \\
0.92)\end{array}$ & $\begin{array}{l}0.052 \\
0.85)\end{array}$ & $\begin{array}{l}0.000 \\
(0.01)\end{array}$ & $\begin{array}{l}0.037 \\
(0.60)\end{array}$ & $\begin{array}{l}0.053 \\
(0.87)\end{array}$ \\
\hline pm25 & $\begin{array}{c}0.556^{* * * *} \\
(8.02)\end{array}$ & $\begin{array}{c}0.569^{* * *} \\
(8.48)\end{array}$ & $\begin{array}{l}0.557^{* * * *} \\
(8.37)\end{array}$ & $\begin{array}{c}0.586^{* * * *} \\
(8.81)\end{array}$ & $\begin{array}{c}0.565^{* * *} \\
(8.15)\end{array}$ & $\begin{array}{l}0.573^{* * *} \\
(8.55)\end{array}$ & $\begin{array}{c}0.559^{* * *} \\
(8.41)\end{array}$ \\
\hline garbage & $\begin{array}{c}0.837^{* * * *} \\
(8.54)\end{array}$ & $\begin{array}{c}0.831^{* * *} \\
(8.76)\end{array}$ & $\begin{array}{c}0.843 * * * * \\
(8.90)\end{array}$ & $\begin{array}{c}0.836 * * * \\
(8.83)\end{array}$ & $\begin{array}{c}0.845 * * * * \\
(8.65)\end{array}$ & $\begin{array}{c}0.830 * * * \\
(8.75)\end{array}$ & $\begin{array}{c}0.847^{* * *} \\
(8.93)\end{array}$ \\
\hline nox & $\begin{array}{l}-0.450 * * \\
(-2.55)\end{array}$ & $\begin{array}{c}-0.459 * * * \\
(-2.73)\end{array}$ & $\begin{array}{l}-0.426 \text { ** } \\
(-2.54)\end{array}$ & $\begin{array}{c}-0.474 * * * * \\
(-2.82)\end{array}$ & $\begin{array}{c}-0.421 \text { ** } \\
(-2.38)\end{array}$ & $\begin{array}{c}-0.472 * * * * \\
(-2.80)\end{array}$ & $\begin{array}{l}-0.428 \text { ** } \\
(-2.55)\end{array}$ \\
\hline so2 & $\begin{array}{c}0.323^{* * *} \\
(3.11)\end{array}$ & $\begin{array}{c}0.298^{* * *} \\
(2.98)\end{array}$ & $\begin{array}{c}0.299 * * * \\
(3.00)\end{array}$ & $\begin{array}{c}0.305^{* * *} \\
(3.05)\end{array}$ & $\begin{array}{c}0.308^{* * *} \\
(2.95)\end{array}$ & $\begin{array}{c}0.296 * * * \\
(2.96)\end{array}$ & $\begin{array}{c}0.298 * * * \\
(2.98)\end{array}$ \\
\hline wat poll & $\begin{array}{c}-0.966 * * * \\
(-9.72)\end{array}$ & $\begin{array}{c}-0.982 * * * \\
(-10.28)\end{array}$ & $\begin{array}{c}-0.994 * * * \\
(-10.42)\end{array}$ & $\begin{array}{c}-0.994 * * * * \\
(-10.44)\end{array}$ & $\begin{array}{c}-0.968 * * * * \\
(-9.77)\end{array}$ & $\begin{array}{c}-0.984 * * * * \\
(-10.31)\end{array}$ & $\begin{array}{c}-0.997 * * * \\
(-10.46)\end{array}$ \\
\hline smoke & $\begin{array}{l}0.102 \\
(0.81)\end{array}$ & $\begin{array}{l}0.175 \\
(1.45)\end{array}$ & $\begin{array}{l}0.145 \\
(1.20)\end{array}$ & $\begin{array}{l}0.197 \\
(1.64)\end{array}$ & $\begin{array}{l}0.084 \\
(0.67)\end{array}$ & $\begin{array}{l}0.192 \\
(1.60)\end{array}$ & $\begin{array}{l}0.147 \\
(1.22)\end{array}$ \\
\hline $\mathrm{N}$ & 6211 & 6825 & 6825 & 6826 & 6212 & 6826 & 6826 \\
\hline
\end{tabular}

Notes: Asterisks indicate the statistical significance, where ${ }^{* * *}, * *$, and ${ }^{*}$ represent significance at $1 \%, 5 \%$, and $10 \%$ levels. The parentheses show $t$ values of robust standard error. The results in this table are estimated by an ordered logit model.

Table A8. The effect of individual-level income inequality on subjective environmental pollution: robustness test based on cluster analysis and an ordered probit model.

\begin{tabular}{|c|c|c|c|c|}
\hline & (1) & (2) & (3) & (4) \\
\hline & clustered at province level & clustered at city level & clustered at county level & probit \\
\hline inequality & $\begin{array}{c}1.317^{* * *} \\
(2.39)\end{array}$ & $\begin{array}{c}1.317 * * \\
(2.46)\end{array}$ & $\begin{array}{c}1.317 * * \\
(2.53)\end{array}$ & $\begin{array}{c}0.737 \text { *** } \\
(3.11)\end{array}$ \\
\hline inequality $^{2}$ & $\begin{array}{c}-0.077 * * \\
(-2.36)\end{array}$ & $\begin{array}{c}-0.077^{* *} \\
(-2.41)\end{array}$ & $\begin{array}{l}-0.077 * * * \\
(-2.59)\end{array}$ & $\begin{array}{c}-0.043 * * * \\
(-3.17)\end{array}$ \\
\hline lnphi & $\begin{array}{c}0.165 * * * \\
(3.95)\end{array}$ & $\begin{array}{c}0.165^{* * *} \\
(3.47)\end{array}$ & $\begin{array}{c}0.165 * * * \\
(3.40)\end{array}$ & $\begin{array}{c}0.088 * * * \\
(4.59)\end{array}$ \\
\hline env behavior & $\begin{array}{c}0.451^{* * *} \\
(3.35)\end{array}$ & $\begin{array}{c}0.451 \text { *** } \\
(3.39)\end{array}$ & $\begin{array}{c}0.451 \text { *** } \\
(4.33)\end{array}$ & $\begin{array}{c}0.248 * * * \\
(6.70)\end{array}$ \\
\hline env know & $\begin{array}{c}0.070 * * * \\
(4.01)\end{array}$ & $\begin{array}{c}0.070^{* * *} \\
(3.83)\end{array}$ & $\begin{array}{c}0.070^{* * * *} \\
(4.25)\end{array}$ & $\begin{array}{c}0.042 * * * \\
(7.85)\end{array}$ \\
\hline \multirow[t]{2}{*}{ gender } & $-0.078^{*}$ & -0.078 & -0.078 & $-0.046^{*}$ \\
\hline & $(-1.67)$ & $(-1.40)$ & $(-1.61)$ & $(-1.73)$ \\
\hline env attitude & $\begin{array}{c}0.087^{* * *} \\
(2.26)\end{array}$ & $\begin{array}{c}0.087^{*} \\
(1.94)\end{array}$ & $\begin{array}{c}0.087^{* * *} \\
(2.04)\end{array}$ & $\begin{array}{c}0.052 * * * * \\
(3.29)\end{array}$ \\
\hline ind cong & $\begin{array}{l}0.223 * * * \\
(3.34)\end{array}$ & $0.223^{* * *}$ & $\begin{array}{l}0.223 * * * \\
(3.63)\end{array}$ & $\begin{array}{l}0.132^{* * * *} \\
(628)\end{array}$ \\
\hline \multirow[t]{2}{*}{ health } & $\begin{array}{c}(3.34) \\
-0.005\end{array}$ & $\begin{array}{c}(3.05) \\
-0.005\end{array}$ & $\begin{array}{c}(3.63) \\
-0.005\end{array}$ & $\begin{array}{c}(6.28) \\
-0.003\end{array}$ \\
\hline & $(-0.13)$ & $(-0.15)$ & $(-0.16)$ & $(-0.25)$ \\
\hline \multirow{2}{*}{ well-being } & $-0.168^{* * *}$ & $-0.168 * * *$ & $-0.168 * * *$ & $-0.093 * * *$ \\
\hline & $(-2.98)$ & $(-3.10)$ & $(-4.30)$ & $(-5.73)$ \\
\hline \multirow[t]{2}{*}{$\operatorname{lnPGDP}$} & -6.250 & -6.250 & -6.250 & $-4.794^{*}$ \\
\hline & $\begin{array}{c}(-0.29) \\
0.316\end{array}$ & $\begin{array}{c}(-0.34) \\
0.316\end{array}$ & $\begin{array}{c}(-0.40) \\
0.316\end{array}$ & $(-1.95)$ \\
\hline lnPGDP2 & $\begin{array}{l}0.316 \\
(0.31)\end{array}$ & $\begin{array}{l}.3 .316 \\
(0.37)\end{array}$ & $\begin{array}{l}0.316 \\
(0.43)\end{array}$ & $\begin{array}{c}0.239^{* 74} \\
(2.09)\end{array}$ \\
\hline \multirow[t]{2}{*}{ pop den } & 0.055 & 0.055 & 0.055 & 0.031 \\
\hline & $(0.22)$ & $(0.23)$ & $(0.25)$ & $(0.88)$ \\
\hline \multirow[t]{2}{*}{ pm25 } & 0.573 * & $0.573^{* *}$ & $0.573 * * *$ & $0.334^{* * * *}$ \\
\hline & $(1.77)$ & $(1.98)$ & $(2.61)$ & $(8.74)$ \\
\hline garbage & $\begin{array}{c}0.833^{* *} \\
(2.08)\end{array}$ & $\begin{array}{c}0.833^{* *} \\
(2.23)\end{array}$ & $\begin{array}{c}0.833^{* *} \\
(2.47)\end{array}$ & $0.458^{* * *}$ \\
\hline \multirow{2}{*}{ nox } & $\begin{array}{l}(2.08) \\
-0.463\end{array}$ & $\begin{array}{l}(2.23) \\
-0.463\end{array}$ & $\begin{array}{c}(2.47) \\
-0.463\end{array}$ & $\begin{array}{l}(8.37) \\
-0.28 * *\end{array}$ \\
\hline & $(-0.54)$ & $(-0.63)$ & $(-0.76)$ & $(-2.99)$ \\
\hline \multirow[t]{2}{*}{ so2 } & 0.305 & 0.305 & 0.305 & $0.197 * * *$ \\
\hline & $(0.68)$ & $(0.76)$ & $(0.85)$ & $(3.51)$ \\
\hline \multirow[t]{2}{*}{ wat poll } & $-0.990 * *$ & $-0.990 * * *$ & $-0.990 * * *$ & $-0.547^{* * *}$ \\
\hline & $(-2.25)$ & $(-2.66)$ & $(-2.94)$ & $(-9.98)$ \\
\hline \multirow[t]{2}{*}{ smoke } & 0.186 & 0.186 & 0.186 & $0.120^{*}$ \\
\hline & $(0.30)$ & $(0.34)$ & $(0.41)$ & $(1.80)$ \\
\hline $\mathrm{N}$ & 6825 & 6825 & 6825 & 6825 \\
\hline
\end{tabular}

Note: The parentheses show $t$ statistics, where columns 1-3 are $t$ values of clustering robust standard error. Asterisks indicate the statistical significance, where ${ }^{* * *}, * *$, and ${ }^{*}$ represent significance at $1 \%, 5 \%$, and $10 \%$ levels, respectively. The column 1 clusters are at the province level, column 2 clusters are at the city level, column 3 clusters are at the county level. Column 4 is estimated by an ordered probit model. 
Table A9. The effect of individual-level income inequality on subjective environmental pollution: differences in urban and rural area.

\begin{tabular}{|c|c|c|c|c|c|c|}
\hline & (1) & (2) & (3) & (4) & (5) & (6) \\
\hline & \multicolumn{3}{|c|}{ The urban area } & \multicolumn{3}{|c|}{ The rural area } \\
\hline inequality & $\begin{array}{c}0.982 \text { *** } \\
(2.43)\end{array}$ & $\begin{array}{c}1.219 * * * \\
(2.93)\end{array}$ & $\begin{array}{c}0.931 * * \\
(2.24)\end{array}$ & $\begin{array}{l}-1.029 \\
(-1.27)\end{array}$ & $\begin{array}{l}-1.330 \\
(-1.58)\end{array}$ & $\begin{array}{l}-1.329 \\
(-1.31)\end{array}$ \\
\hline \multirow[t]{2}{*}{ inequality $^{2}$} & $-0.069 * * *$ & $-0.071 * * *$ & $-0.053 * *$ & 0.040 & 0.067 & 0.068 \\
\hline & $(-2.94)$ & $(-2.90)$ & $(-2.18)$ & $(0.90)$ & (1.41) & (1.20) \\
\hline \multirow[t]{2}{*}{ lnphi } & & $0.133 * * * *$ & 0.049 & & 0.076 & 0.041 \\
\hline & & $(2.79)$ & (1.01) & & (1.49) & $(0.79)$ \\
\hline \multirow[t]{2}{*}{ env behavior } & & $0.495^{* * *}$ & $0.471^{* * *}$ & & 0.089 & 0.141 \\
\hline & & (6.80) & (6.41) & & $(0.70)$ & (1.09) \\
\hline \multirow[t]{2}{*}{ env know } & & 0.007 & 0.014 & & $0.110^{* * *}$ & $0.112^{* * *}$ \\
\hline & & (0.63) & (1.19) & & (6.93) & (7.03) \\
\hline \multirow[t]{2}{*}{ gender } & & -0.018 & -0.007 & & $-0.166 * *$ & $-0.137^{*}$ \\
\hline & & $(-0.32)$ & $(-0.13)$ & & $(-2.06)$ & $(-1.70)$ \\
\hline \multirow[t]{2}{*}{ env attitude } & & $0.058^{*}$ & 0.046 & & $0.217^{* * *}$ & $0.223 * * *$ \\
\hline & & (1.72) & (1.34) & & $(4.37)$ & (4.42) \\
\hline \multirow[t]{2}{*}{ ind cong } & & $0.290^{* * * *}$ & $0.260^{* * *}$ & & 0.025 & 0.062 \\
\hline & & $(6.65)$ & $(5.96)$ & & $(0.37)$ & $(0.89)$ \\
\hline \multirow[t]{2}{*}{ health } & & 0.000 & -0.000 & & 0.029 & $\begin{array}{l}0.019 \\
(0.54)\end{array}$ \\
\hline & & $(0.01)$ & $(-0.01)$ & & $(0.83)$ & (0.54) \\
\hline well-being & & $\begin{array}{c}-0.232 * * * \\
(-6.42)\end{array}$ & $\begin{array}{c}-0.217 \text { *** } \\
(-5.97)\end{array}$ & & $\begin{array}{l}-0.020 \\
(-0.44)\end{array}$ & $\begin{array}{l}-0.024 \\
(-0.53)\end{array}$ \\
\hline $\operatorname{lnPGDP}$ & & & $0.495^{* * *}$ & & & $-19.900 * * *$ \\
\hline \multirow[t]{2}{*}{ lnPGDP2 } & & & $(6.77)$ & & & $\begin{array}{l}(-2.60) \\
0.964^{* * *}\end{array}$ \\
\hline & & & & & & $\begin{array}{c}(2.68) \\
0.187 *\end{array}$ \\
\hline pop den & & & (1.01) & & & $(1.85)$ \\
\hline \multirow[t]{2}{*}{ pm25 } & & & 0.076 & & & $0.211^{* * *}$ \\
\hline & & & $(1.20)$ & & & (2.61) \\
\hline $\mathrm{N}$ & 4761 & 4457 & 4457 & 2550 & 2368 & 2368 \\
\hline
\end{tabular}

Notes: The parentheses show $t$ value of robust standard error. Asterisks indicate the statistical significance, where $* * *$, and ${ }^{* * *}$ denote significance at $10 \%, 5 \%$, and $1 \%$ levels, respectively. The results in this table are estimated by an ordered logit model.

Table A10. The effect of individual-level income inequality on subjective environmental pollution: differences between the locals and migrants.

\begin{tabular}{|c|c|c|c|c|c|c|}
\hline & (1) & (2) & (3) & (4) & (5) & (6) \\
\hline & & Local & & & Migrant & \\
\hline inequality & $\begin{array}{c}2.127 * * * \\
(4.40)\end{array}$ & $\begin{array}{l}2.004 * * * \\
(3.80)\end{array}$ & $\begin{array}{c}1.407 * * \\
(2.49)\end{array}$ & $\begin{array}{c}1.312 \text { ** } \\
(2.05)\end{array}$ & $\begin{array}{l}0.943 \\
(1.44)\end{array}$ & $\begin{array}{l}0.393 \\
(0.63)\end{array}$ \\
\hline inequality $^{2}$ & $\begin{array}{c}-0.152 * * * \\
(-5.55)\end{array}$ & $\begin{array}{c}-0.124^{* * *} \\
(-4.12)\end{array}$ & $\begin{array}{c}-0.087 * * * \\
(-2.71)\end{array}$ & $\begin{array}{l}-0.094 \text { ** } \\
(-2.54)\end{array}$ & $\begin{array}{l}-0.048 \\
(-1.25)\end{array}$ & $\begin{array}{l}-0.015 \\
(-0.40)\end{array}$ \\
\hline lnphi & & $\begin{array}{c}0.227 * * * \\
(5.79)\end{array}$ & $\begin{array}{c}0.127^{* * *} \\
(3.25)\end{array}$ & & $\begin{array}{c}0.308^{* * * *} \\
(4.48)\end{array}$ & $\begin{array}{l}0.222 * * * \\
(3.19)\end{array}$ \\
\hline env behavior & & $\begin{array}{c}0.426 * * * \\
(5.07)\end{array}$ & $\begin{array}{c}0.428^{* * *} \\
(4.93)\end{array}$ & & $\begin{array}{c}0.457^{* * * *} \\
(4.66)\end{array}$ & $\begin{array}{c}0.471^{* * *} \\
(4.42)\end{array}$ \\
\hline env know & & $\begin{array}{c}0.079 * * * \\
(7.10)\end{array}$ & $\begin{array}{c}0.080^{* * *} \\
(7.20)\end{array}$ & & $\begin{array}{l}0.026 \\
(1.48)\end{array}$ & $\begin{array}{c}0.044 * * \\
(2.56)\end{array}$ \\
\hline gender & & $\begin{array}{c}-0.229^{* * *} \\
(-4.18)\end{array}$ & $\begin{array}{c}-0.176^{* * *} \\
(-3.22)\end{array}$ & & $\begin{array}{c}0.243 * * * * \\
(2.73)\end{array}$ & $\begin{array}{c}0.226^{* *} \\
(2.54)\end{array}$ \\
\hline env attitude & & $\begin{array}{c}0.108^{* * * *} \\
(3.31)\end{array}$ & $\begin{array}{c}0.095^{* * *} \\
(2.81)\end{array}$ & & $\begin{array}{l}0.087^{*} \\
(1.75)\end{array}$ & $\begin{array}{l}0.101^{* *} \\
(1.99)\end{array}$ \\
\hline ind cong & & $\begin{array}{c}0.351^{* * *} \\
(7.89)\end{array}$ & $\begin{array}{c}0.298 * * * \\
(6.54)\end{array}$ & & $\begin{array}{l}0.105 \\
(1.60)\end{array}$ & $\begin{array}{l}0.055 \\
(0.83)\end{array}$ \\
\hline health & & $\begin{array}{c}-0.072 * * * * \\
(-2.70)\end{array}$ & $\begin{array}{c}-0.061^{* *} \\
(-2.24)\end{array}$ & & $\begin{array}{c}0.143^{* * *} \\
(3.41)\end{array}$ & $\begin{array}{c}0.1333^{* * * *} \\
(3.10)\end{array}$ \\
\hline well-being & & $\begin{array}{c}-0.210 * * * \\
(-6.21)\end{array}$ & $\begin{array}{c}-0.191^{* * * *} \\
(-5.55)\end{array}$ & & $\begin{array}{c}-0.157^{* * *} \\
(-3.05)\end{array}$ & $\begin{array}{c}-0.112 \text { ** } \\
(-2.11)\end{array}$ \\
\hline $\operatorname{lnPGDP}$ & & & $\begin{array}{c}-10.552 \text { ** } \\
(-2.10)\end{array}$ & & & $\begin{array}{l}1.126 \\
(0.13)\end{array}$ \\
\hline lnPGDP2 & & & $\begin{array}{c}0.516^{* * *} \\
(2.21)\end{array}$ & & & $\begin{array}{l}-0.023 \\
(-0.06)\end{array}$ \\
\hline pop den & & & $\begin{array}{l}0.078 \\
(1.08)\end{array}$ & & & $\begin{array}{l}0.006 \\
(0.04)\end{array}$ \\
\hline pm25 & & & $\begin{array}{c}0.477^{* * *} \\
(6.20)\end{array}$ & & & $\begin{array}{c}0.905^{* * *} \\
(6.14)\end{array}$ \\
\hline garbage & & & $\begin{array}{c}0.893 * * * \\
(7.78)\end{array}$ & & & $\begin{array}{c}0.544 * * * \\
(2.83)\end{array}$ \\
\hline nox & & & $\begin{array}{l}-0.377^{*} \\
(-1.93)\end{array}$ & & & $\begin{array}{l}-0.301 \\
(-0.81)\end{array}$ \\
\hline so2 & & & $\begin{array}{c}0.309 * * * \\
(2.69)\end{array}$ & & & $\begin{array}{l}0.192 \\
(0.91)\end{array}$ \\
\hline wat poll & & & $\begin{array}{c}-0.931 * * * \\
(-8.36)\end{array}$ & & & $\begin{array}{c}-1.109 * * * \\
(-5.58)\end{array}$ \\
\hline smoke & & & $\begin{array}{l}0.135 \\
(0.94)\end{array}$ & & & $\begin{array}{l}0.184 \\
(0.75)\end{array}$ \\
\hline $\mathrm{N}$ & 5241 & 4885 & 4885 & 2069 & 1940 & 1940 \\
\hline
\end{tabular}

Notes: The parentheses show $t$ values of robust standard error. Asterisks indicates the statistical significance, where $* * *$, and ${ }^{* * *}$ denote significance at $10 \%, 5 \%$, and $1 \%$ levels, respectively. The results in this table are estimated by ordered logit model. 
Table A11. The effect of individual-level income inequality on subjective environmental pollution: differences in gender.

\begin{tabular}{|c|c|c|c|c|c|c|}
\hline & (1) & (2) & (3) & (4) & (5) & (6) \\
\hline & \multicolumn{3}{|c|}{ The female group } & \multicolumn{3}{|c|}{ The male group } \\
\hline inequality & $\begin{array}{c}2.958 * * * \\
(3.71)\end{array}$ & $\begin{array}{c}2.700 * * * * \\
(3.02)\end{array}$ & $\begin{array}{c}1.977 * * \\
(2.26)\end{array}$ & $\begin{array}{c}2.023 * * * \\
(4.48)\end{array}$ & $\begin{array}{c}1.763 * * * \\
(3.87)\end{array}$ & $\begin{array}{c}1.237 * * * \\
(2.59)\end{array}$ \\
\hline inequality $^{2}$ & $-0.195 * * *$ & $-0.155^{* * *}$ & $-0.1111^{* *}$ & $-0.148 * * *$ & $-0.106^{* * *}$ & $-0.074 * * *$ \\
\hline lnphi & $(-4.40)$ & $\begin{array}{c}(-3.13) \\
0.217 * * * \\
(4.67)\end{array}$ & $\begin{array}{c}(-2.28) \\
0.135^{* * *} \\
(2.96)\end{array}$ & $(-5.64)$ & $\begin{array}{c}(-3.92) \\
0.306 * * * \\
(6.22)\end{array}$ & $\begin{array}{c}(-2.61) \\
0.198^{* * *}\end{array}$ \\
\hline env behavior & & $\begin{array}{c}0.649 * * * * \\
(6.55)\end{array}$ & $\begin{array}{c}0.625 * * * \\
(5.98)\end{array}$ & & $\begin{array}{c}0.285 * * * \\
(3.38)\end{array}$ & $\begin{array}{c}0.318^{* * *} \\
(3.64)\end{array}$ \\
\hline env know & & $\begin{array}{c}0.070^{* * *} \\
(5.00)\end{array}$ & $\begin{array}{l}0.072^{* * *} \\
(5.23)\end{array}$ & & $\begin{array}{c}0.056^{* * * *} \\
(4.44)\end{array}$ & $\begin{array}{c}0.067 * * * \\
(5.32)\end{array}$ \\
\hline env attitude & & $\begin{array}{c}0.128^{* * * *} \\
(3.34)\end{array}$ & $\begin{array}{c}0.124 * * * \\
(3.13)\end{array}$ & & $\begin{array}{l}0.058 \\
(1.50)\end{array}$ & $\begin{array}{l}0.051 \\
(1.28)\end{array}$ \\
\hline ind cong & & $\begin{array}{c}0.236 * * * \\
(4.41)\end{array}$ & $\begin{array}{c}0.207^{* * *} \\
(3.86)\end{array}$ & & $\begin{array}{c}0.338 * * * \\
(6.64)\end{array}$ & $\begin{array}{c}0.251^{* * *} \\
(4.79)\end{array}$ \\
\hline health & & $\begin{array}{l}-0.025 \\
(-0.77)\end{array}$ & $\begin{array}{l}-0.028 \\
(-0.84)\end{array}$ & & $\begin{array}{l}0.003 \\
(0.10)\end{array}$ & $\begin{array}{l}0.011 \\
(0.35)\end{array}$ \\
\hline wellbeing & & $\begin{array}{c}-0.161 * * * \\
(-3.85)\end{array}$ & $\begin{array}{c}-0.134 * * * \\
(-3.17)\end{array}$ & & $\begin{array}{c}-0.226 * * * \\
(-5.89)\end{array}$ & $\begin{array}{c}-0.199 * * * * \\
(-5.08)\end{array}$ \\
\hline $\operatorname{lnPGDP}$ & & & $\begin{array}{l}-7.381 \\
(-1.16)\end{array}$ & & & $\begin{array}{l}-5.540 \\
(-0.96)\end{array}$ \\
\hline InPGDP2 & & & $\begin{array}{l}0.379 \\
(1.28)\end{array}$ & & & $\begin{array}{l}0.275 \\
(1.02)\end{array}$ \\
\hline pop den & & & $\begin{array}{c}0.155^{*} \\
(1.68)\end{array}$ & & & $\begin{array}{l}-0.018 \\
(-0.23)\end{array}$ \\
\hline $\mathrm{pm} 25$ & & & $\begin{array}{c}0.531 * * * \\
(5.25)\end{array}$ & & & $\begin{array}{c}0.591 * * * \\
(6.73)\end{array}$ \\
\hline garbage & & & $\begin{array}{c}0.713 * * * \\
(5.02)\end{array}$ & & & $\begin{array}{c}0.921 * * * \\
(7.18)\end{array}$ \\
\hline nox & & & $\begin{array}{c}-0.6455^{* * * *} \\
(-2.59)\end{array}$ & & & $\begin{array}{l}-0.339 \\
(-1.49)\end{array}$ \\
\hline so2 & & & $\begin{array}{c}0.402 * * * \\
(2.64)\end{array}$ & & & $\begin{array}{c}0.238^{*} \\
(1.80)\end{array}$ \\
\hline wat poll & & & $\begin{array}{c}-0.942 * * * \\
(-6.61)\end{array}$ & & & $\begin{array}{c}-1.008 * * * \\
(-7.79)\end{array}$ \\
\hline smoke & & & $\begin{array}{c}0.336^{*} \\
(1.90)\end{array}$ & & & $\begin{array}{l}0.066 \\
(0.40)\end{array}$ \\
\hline $\mathrm{N}$ & 3372 & 3124 & 3124 & 3942 & 3704 & 3704 \\
\hline
\end{tabular}

Notes: The parentheses show $t$ values of robust standard error. Asterisks indicate the statistical significance, where $* * *$, and ${ }^{* * *}$ denote significance at $10 \%, 5 \%$, and $1 \%$ levels, respectively.

Table A12. The effect of individual-level income inequality on subjective environmental pollution: differences in environmental attitude.

\begin{tabular}{|c|c|c|c|c|c|c|}
\hline & (1) & (2) & (3) & (4) & (5) & (6) \\
\hline & \multicolumn{3}{|c|}{ Negative attitude group } & \multicolumn{3}{|c|}{ Positive attitude group } \\
\hline inequality & $\begin{array}{c}1.872 * * * \\
(3.90)\end{array}$ & $\begin{array}{c}1.588 * * * \\
(3.10)\end{array}$ & $\begin{array}{c}0.858 * \\
(1.67)\end{array}$ & $\begin{array}{c}2.312 * * * \\
(3.51)\end{array}$ & $\begin{array}{c}2.447^{* * *} \\
(3.62)\end{array}$ & $\begin{array}{c}2.143^{* * *} \\
(3.11)\end{array}$ \\
\hline \multirow[t]{2}{*}{ inequality $^{2}$} & $-0.134 * * *$ & $-0.095 * * *$ & -0.051 * & $-0.158^{* * *}$ & $-0.146^{* * *}$ & $-0.127^{* * *}$ \\
\hline & $(-4.95)$ & $(-3.26)$ & $(-1.73)$ & $(-4.07)$ & $(-3.61)$ & $(-3.06)$ \\
\hline \multirow[t]{2}{*}{ Inphi } & & $0.269^{* * *}$ & $0.177 * * *$ & & $0.209 * *$ & 0.097 \\
\hline & & $(7.30)$ & $(4.81)$ & & (2.42) & (1.14) \\
\hline env behavior & & $\begin{array}{c}0.438 * * * \\
(5.91)\end{array}$ & $\begin{array}{l}0.441 * * * \\
(578)\end{array}$ & & $0.411^{* * * *}$ & $0.411^{* * *}$ \\
\hline \multirow[t]{2}{*}{ env know } & & $0.064^{* * *}$ & $0.069^{* * *}$ & & $0.049^{*}$ & $0.067 * *$ \\
\hline & & $(6.39)$ & $(6.90)$ & & (1.96) & $(2.56)$ \\
\hline gender & & $\begin{array}{c}-0.111 * * \\
(-2.16)\end{array}$ & $\begin{array}{l}-0.072 \\
(-1.41)\end{array}$ & & $\begin{array}{l}-0.159 \\
(-1.44)\end{array}$ & $\begin{array}{l}-0.137 \\
(-1.23)\end{array}$ \\
\hline \multirow{2}{*}{ ind cong } & & $0.285 * * *$ & $0.232^{* * *}$ & & $0.273^{* * *}$ & $0.220 * *$ \\
\hline & & $(6.97)$ & $(5.63)$ & & $(3.26)$ & $(2.56)$ \\
\hline health & & $\begin{array}{l}-0.011 \\
(-0.44)\end{array}$ & -0.001 & & -0.018 & -0.043 \\
\hline \multirow{2}{*}{ well-being } & & $\begin{aligned} & (-0.44) \\
-0.186 * * * & \end{aligned}$ & $\begin{array}{l}(-0.06) \\
-0.166 * *\end{array}$ & & $\begin{array}{l}(-0.31) \\
-0.246 * * \\
\end{array}$ & $\begin{array}{l}(-0.70) \\
-0.202 * * *\end{array}$ \\
\hline & & $(-6.07)$ & $(-5.34)$ & & $(-3.39)$ & $(-2.72)$ \\
\hline \multirow[t]{2}{*}{$\ln P G D P$} & & & -1.561 & & & -12.847 \\
\hline & & & $(-0.42)$ & & & $(-1.23)$ \\
\hline \multirow[t]{2}{*}{ lnPGDP2 } & & & 0.100 & & & 0.602 \\
\hline & & & $(0.58)$ & & & (1.24) \\
\hline pop den & & & 0.053 & & & 0.022 \\
\hline \multirow[t]{2}{*}{ pm25 } & & & $0.529^{* * * *}$ & & & $0.720 * * *$ \\
\hline & & & $(7.86)$ & & & $(3.96)$ \\
\hline \multirow[t]{2}{*}{ garbage } & & & $0.790^{* * *}$ & & & $0.963^{* * *}$ \\
\hline & & & $(7.54)$ & & & $(4.16)$ \\
\hline \multirow[t]{2}{*}{ nox } & & & $-0.294 * *$ & & & -0.360 \\
\hline & & & $\begin{array}{l}(-2.24) \\
0.343^{* * *}\end{array}$ & & & $\begin{array}{c}(-0.81) \\
0.111\end{array}$ \\
\hline so2 & & & $(3.21)$ & & & $(0.40)$ \\
\hline \multirow[t]{2}{*}{ wat poll } & & & $-1.059 * * *$ & & & $-0.820 * * *$ \\
\hline & & & $(-10.49)$ & & & $(-3.45)$ \\
\hline \multirow[t]{2}{*}{ smoke } & & & & & & 0.227 \\
\hline & & & & & & $(0.79)$ \\
\hline $\mathrm{N}$ & 6105 & 5696 & 5696 & 1209 & 1132 & 1132 \\
\hline
\end{tabular}

Notes: The parentheses show $t$ values of robust standard error. Asterisks indicate the statistical significance, where ${ }^{* *}$, and ${ }^{* * *}$ denote significance at $10 \%, 5 \%$, and $1 \%$ levels, respectively. 
Table A13. The mechanism of the effect of individual-level income inequality on subjective environmental pollution.

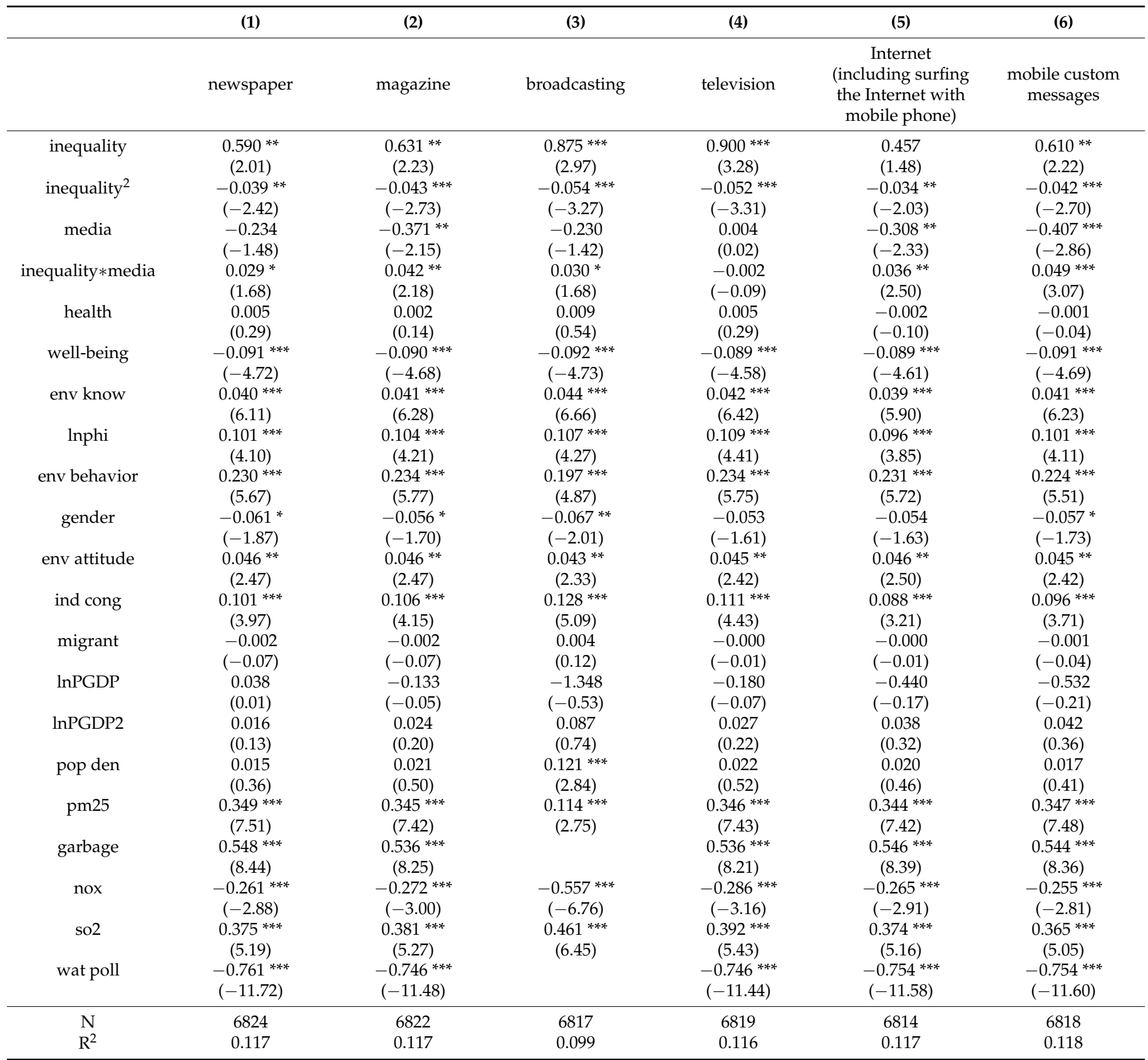

Notes: The parentheses show $t$ values of robust standard error. Asterisks indicate the statistical significance, where ${ }^{*},{ }^{* *}$, and ${ }^{* * *}$ denote significance at $10 \%, 5 \%$, and $1 \%$ levels, respectively. The results in this table are estimated by OLS.

\section{References}

1. Luo, C.; Li, S.; Sicular, T. The long-term evolution of national income inequality and rural poverty in China. China Econ. Rev. 2020, 62, 101465. [CrossRef]

2. Lei, X.; Shen, Y.; Smith, J.P.; Zhou, G. Life satisfaction in China and consumption and income inequalities. Rev. Econ. Househ. 2017, 16, 75-95. [CrossRef]

3. Shao, S.; Tian, Z.; Fan, M. Do the rich have stronger willingness to pay for environmental protection? New evidence from a survey in China. World Dev. 2018, 105, 83-94. [CrossRef]

4. Hao, Y.; Deng, Y.; Lu, Z.-N.; Chen, H. Is environmental regulation effective in China? Evidence from city-level panel data. J. Clean. Prod. 2018, 188, 966-976. [CrossRef]

5. Yang, J.; Yang, Z.; Sheng, P. Income Distribution, Human Capital and Environmental Quality: Empirical Study in China. Energy Procedia 2011, 5, 1689-1696. 
6. Li, B.; Cheng, S.; Xiao, D. The impacts of environmental pollution and brain drain on income inequality. China Econ. Rev. 2020, 62, 101481. [CrossRef]

7. Uddin, M.; Mishra, V.; Smyth, R. Income inequality and $\mathrm{CO}_{2}$ emissions in the G7, 1870-2014: Evidence from non-parametric modelling. Energy Econ. 2020, 88, 104780. [CrossRef]

8. Sager, L. Income inequality and carbon consumption: Evidence from Environmental Engel curves. Energy Econ. $2019,84,104507$. [CrossRef]

9. Hausman, C.; Stolper, S. Inequality, information failures, and air pollution. In Inequality, Information Failures, and Air Pollution; National Bureau of Economic Research: Cambridge, MA, USA, 2020.

10. Yang, B.; Ali, M.; Hashmi, S.H.; Shabir, M. Income Inequality and $\mathrm{CO}_{2}$ Emissions in Developing Countries: The Moderating Role of Financial Instability. Sustainability 2020, 12, 6810. [CrossRef]

11. Li, F.; Zhou, T. Effects of objective and subjective environmental pollution on well-being in urban China: A structural equation model approach. Soc. Sci. Med. 2020, 249, 112859. [CrossRef] [PubMed]

12. Zhang, J.; Cheng, M.; Yu, N. Internet Use and Lower Life Satisfaction: The Mediating Effect of Environmental Quality Perception. Ecol. Econ. 2020, 176, 106725. [CrossRef]

13. Zhang, L.; Wu, L. Effects of Environmental Quality Perception on Depression: Subjective Social Class as a Mediator. Int. J. Environ. Res. Public Health 2021, 18, 6130. [CrossRef]

14. Hastings, O.P. Who feels it? Income inequality, relative deprivation, and financial satisfaction in U.S. states, 1973-2012. Res. Soc. Strat. Mobil. 2019, 60, 1-15. [CrossRef]

15. Kondo, N.; Kawachi, I.; Subramanian, S.V.; Takeda, Y.; Yamagata, Z. Do social comparisons explain the association between income inequality and health?: Relative deprivation and perceived health among male and female Japanese in-dividuals. Soc. Sci. Med. 2008, 67, 982-987. [CrossRef]

16. Dieckmann, O. Income inequality and economic growth in an open economy. Int. Adv. Econ. Res. 1996, 2, 270-278. [CrossRef]

17. Jung, F.; Sunde, U. Income, inequality, and the stability of democracy-Another look at the Lipset hypothesis. Eur. J. Political Econ. 2014, 35, 52-74. [CrossRef]

18. Okazaki, T. Economic Development, Income Inequality and Social Stability in Prewar Japan: A Prefecture-Level Analysis; CIRJE, Faculty of Economics, University of Tokyo: Tokyo, Japan, 2007.

19. Graafland, J.; Lous, B. Income Inequality, Life Satisfaction Inequality and Trust: A Cross Country Panel Analysis. J. Happiness Stud. 2019, 20, 1717-1737. [CrossRef]

20. Pabayo, R.; Fuller, D.; Goldstein, R.; Kawachi, I.; Gilman, S. Income inequality among American states and the conditional risk of post-traumatic stress disorder. Soc. Psychiatry Psychiatr. Epidemiol. 2017, 52, 1195-1204. [CrossRef] [PubMed]

21. Hildebrand, V.; Van Kerm, P. Income inequality and self-rated health status: Evidence from the european community household panel. Demography 2009, 46, 805-825. [CrossRef] [PubMed]

22. Paul, S. Income Inequality and Individual Health Status: Evidence from India. J. Quant. Econ. 2021, 19, 269-289. [CrossRef]

23. Huang, Y.; Ren, G.; Zhou, Y. The Impact of Income Inequality on the Physical and Mental Health of the Rural Residents: Empirical Analysis Based on CGSS2015. J. Agrotech. Econ. 2019, 3, 25-37. (In Chinese)

24. Kakwani, N.; Son, H.H. Social Welfare Functions and Development: Measurement and Policy Application; Palgrave Macmillan Books; Palgrave Macmillan: London, UK, 2016.

25. Schalembier, B. An Evaluation of Common Explanations for the Impact of Income Inequality on Life Satisfaction. J. Happiness Stud. 2018, 20, 777-794. [CrossRef]

26. Wang, P.; Pan, J.; Luo, Z. The Impact of Income Inequality on Individual Happiness: Evidence from China. Soc. Indic. Res. 2015, 121, 413-435. [CrossRef]

27. Zagorski, K.; Evans, M.D.R.; Kelley, J.; Piotrowska, K. Does National Income Inequality Affect Individuals' Quality of Life in Europe? Inequality, Happiness, Finances, and Health. Soc. Indic. Res. 2014, 117, 1089-1110. [CrossRef]

28. Ding, J.; Salinas-Jiménez, J.; Salinas-Jiménez, M.D.M. The Impact of Income Inequality on Subjective Well-Being: The Case of China. J. Happiness Stud. 2021, 22, 845-866. [CrossRef]

29. Reyes-García, V.; Angelsen, A.; Shively, G.E.; Minkin, D. Does Income Inequality Influence Subjective Wellbeing? Evidence from 21 Developing Countries. J. Happiness Stud. 2019, 20, 1197-1215. [CrossRef]

30. Liao, P.-S.; Shaw, D.; Lin, Y.-M. Environmental Quality and Life Satisfaction: Subjective Versus Objective Measures of Air Quality. Soc. Indic. Res. 2014, 124, 599-616. [CrossRef]

31. Chiarini, B.; D'Agostino, A.; Marzano, E.; Regoli, A. The perception of air pollution and noise in urban environments: A subjective indicator across European countries. J. Environ. Manag. 2020, 263, 110272. [CrossRef]

32. Pantavou, K.; Psiloglou, B.; Lykoudis, S.; Mavrakis, A.; Nikolopoulos, G.K. Perceived air quality and particulate matter pollution based on field survey data during a winter period. Int. J. Biometeorol. 2018, 62, 2139-2150. [CrossRef]

33. Mínguez, R.; Montero, J.; Fernández-Avilés, G. Measuring the impact of pollution on property prices in Madrid: Objective versus subjective pollution indicators in spatial models. J. Geogr. Syst. 2013, 15, 169-191. [CrossRef]

34. Soares, J.; Miguel, I.; Venâncio, C.; Lopes, I.; Oliveira, M. Public views on plastic pollution: Knowledge, perceived impacts, and pro-environmental behaviours. J. Hazard. Mater. 2021, 412, 125227. [CrossRef] [PubMed]

35. Kohlhuber, M.; Mielck, A.; Weiland, S.K.; Bolte, G. Social inequality in perceived environmental exposures in relation to housing conditions in Germany. Environ. Res. 2006, 101, 246-255. [CrossRef] 
36. Jacobs, S.V.; Evans, G.W.; Catalano, R.; Dooley, D. Air Pollution and Depressive Symptomatology: Exploratory Analyses of Intervening Psychosocial Factors. Popul. Environ. 1984, 7, 260-272. [CrossRef]

37. Tu, M.; Zhang, B.; Xu, J.; Lu, F. Mass media, information and demand for environmental quality: Evidence from the “Under the Dome." J. Dev. Econ. 2020, 143, 102402. [CrossRef]

38. Feigenbaum, J.; Fishback, P.; Grayson, K. Inequality and the Safety Net Throughout the Income Distribution, 1929-1940. Net Throughout Income Distrib. 2020. [CrossRef]

39. Kuznets, S. Economic Growth and Income Inequality. Am. Econ. Rev. 1955, 45, 1-28.

40. Fodha, M.; Zaghdoud, O. Economic growth and pollutant emissions in Tunisia: An empirical analysis of the envi-ronmental Kuznets curve. Energy Policy 2010, 38, 1150-1156. [CrossRef]

41. Grossman, G.M.; Krueger, A.B. Environmental Impacts of a North American Free Trade Agreement; NBER Working Paper, No. 3914; NBER: Cambridge, MA, USA, 1991. [CrossRef]

42. Boyce, J.K. Inequality as a cause of environmental degradation. Ecol. Econ. 1994, 11, 169-178. [CrossRef]

43. Scruggs, A.L. Political and economic inequality and the environment. Ecol. Econ. 1998, 26, 259-275. [CrossRef]

44. Chen, J.; Xian, Q.; Zhou, J.; Li, D. Impact of income inequality on $\mathrm{CO}_{2}$ emissions in G20 countries. J. Environ. Manag. 2020, 271, 110987. [CrossRef]

45. Ravallion, M.; Heil, M.; Jalan, J. Carbon emissions and income inequality. Oxf. Econ. Pap. 2000, 52, 651-669. [CrossRef]

46. Jorgenson, A.; Schor, J.; Huang, X. Income Inequality and Carbon Emissions in the United States: A State-level Analysis, 1997-2012. Ecol. Econ. 2017, 134, 40-48. [CrossRef]

47. Baležentis, T.; Liobikienè, G.; Štreimikienè, D.; Sun, K. The impact of income inequality on consumption-based green-house gas emissions at the global level: A partially linear approach. J. Environ. Manag. 2020, 267, 110635. [CrossRef]

48. Bowles, S.; Park, Y. Emulation, Inequality, and Work Hours: Was Thorsten Veblen Right? Econ. J. 2005, 115, F397-F412. [CrossRef]

49. Grunewald, N.; Klasen, S.; Martínez-Zarzoso, I.; Muris, C. The Trade-off Between Income Inequality and Carbon Di-oxide Emissions. Ecol. Econ. 2017, 142, 249-256. [CrossRef]

50. Baek, J.; Gweisah, G. Does income inequality harm the environment?: Empirical evidence from the United States. Energy Policy 2013, 62, 1434-1437. [CrossRef]

51. Kasuga, H.; Takaya, M. Does inequality affect environmental quality? Evidence from major Japanese cities. J. Clean. Prod. 2017, 142, 3689-3701. [CrossRef]

52. Padhan, H.; Haouas, I.; Sahoo, B.; Heshmati, A. What matters for environmental quality in the Next Eleven Countries: Economic growth or income inequality? Environ. Sci. Pollut. Res. 2019, 26, 23129-23148. [CrossRef]

53. Heerink, N.; Mulatu, A.; Bulte, E. Income inequality and the environment: Aggregation bias in environmental Kuznets curves. Ecol. Econ. 2001, 38, 359-367. [CrossRef]

54. Mader, $\mathrm{S}$. The nexus between social inequality and $\mathrm{CO}_{2}$ emissions revisited: Challenging its empirical validity. Environ. Sci. Policy 2018, 89, 322-329. [CrossRef]

55. Hao, Y.; Chen, H.; Zhang, Q. Will income inequality affect environmental quality? Analysis based on China's provincial panel data. Ecol. Indic. 2016, 67, 533-542. [CrossRef]

56. Zhang, C.; Zhao, W. Panel estimation for income inequality and $\mathrm{CO}_{2}$ emissions: A regional analysis in China. Appl. Energy 2014, 136, 382-392. [CrossRef]

57. Liu, Q.; Wang, S.; Zhang, W.; Li, J.; Kong, Y. Examining the effects of income inequality on $\mathrm{CO}_{2}$ emissions: Evidence from non-spatial and spatial perspectives. Appl. Energy 2019, 236, 163-171. [CrossRef]

58. Zhou, A.; Li, J. Impact of income inequality and environmental regulation on environmental quality: Evidence from China. J. Clean. Prod. 2020, 274, 123008. [CrossRef]

59. Golley, J.; Meng, X. Income inequality and carbon dioxide emissions: The case of Chinese urban households. Energy Econ. 2012, 34, 1864-1872. [CrossRef]

60. Fehr, E.; Schmidt, K.M. A Theory of Fairness, Competition, and Cooperation. Q. J. Econ. 1999, 114, 817-868. [CrossRef]

61. Caner, A.; Yiğit, Y.C. Relative deprivation and its association with health indicators: Lower inequality may not improve health. SSM Popul. Heal. 2019, 7, 100381. [CrossRef]

62. Adjaye-Gbewonyo, K.; Kawachi, I. Use of the Yitzhaki Index as a test of relative deprivation for health outcomes: A review of recent literature. Soc. Sci. Med. 2012, 75, 129-137. [CrossRef]

63. Jones, A.; Wildman, J. Health, income and relative deprivation: Evidence from the BHPS. J. Heal. Econ. 2008, 27, 308-324. [CrossRef] [PubMed]

64. Song, Y.; Zhou, A.; Zhang, M.; Wang, H. Assessing the effects of haze pollution on subjective well-being based on Chinese General Social Survey. J. Clean. Prod. 2019, 235, 574-582. [CrossRef]

65. Wu, R.; Xie, Z. Identifying the impacts of income inequality on $\mathrm{CO}_{2}$ emissions: Empirical evidences from OECD countries and non-OECD countries. J. Clean. Prod. 2020, 277, 123858. [CrossRef]

66. Baron, R.M.; Kenny, D.A. The moderator-mediator variable distinction in social psychological research: Conceptual, strategic, and statistical considerations. J. Pers. Soc. Psychol. 1986, 51, 1173-1182. [CrossRef]

67. Barwick, P.J.; Li, S.; Lin, L.; Zou, E. From Fog to Smog: The Value of Pollution Information. Fog Smog Value Pollut. Inf. 2019. [CrossRef]

68. Lu, S.; Sun, Z. Study on the mass media and public environmental behavior. J. Arid. Land Resour. Environ. 2018, 32, 43-49. (In Chinese) 